NBER WORKING PAPER SERIES

\author{
FOREIGN COMPETITION, MARKET \\ POWER, AND WAGE INEQUALITY: \\ THEORY AND EVIDENCE
}

George J. Borjas

Valerie A. Ramey

Working Paper No. 4556

\author{
NATIONAL BUREAU OF ECONOMIC RESEARCH \\ 1050 Massachusetts Avenue \\ Cambridge, MA 02138 \\ December 1993
}

We wish to thank Cameron Odgers, Farshid Vahid, and Joao Issler for outstanding research assistance and Garey Ramey and Vince Crawford for helpful suggestions. We both gratefully acknowledge financial support from the National Science Foundation. This paper is part of NBER's research program in Labor Studies. Any opinions expressed are those of the authors and not those of the National Bureau of Economic Research. 
NBER Working Paper \#4556

December 1993

\title{
FOREIGN COMPETITION, MARKET \\ POWER, AND WAGE INEQUALITY: \\ THEORY AND EVIDENCE
}

\begin{abstract}
In this paper, we present theory and evidence on the link between wage inequality and foreign competition in concentrated industries. We develop a simple model in which the impact of foreign competition on the relative wages of an economy depends on the market structure of the industry penetrated. We show that the more concentrated is the industry, the greater is the impact of trade on general wage inequality. We use the theory to argue why import competition in an industry such as automobiles is much more deleterious to the wages of the less educated than import competition in an industry such as apparel. We then test our hypothesis using a panel data set on relative wages across SMSAs. We reinterpret our model as a model of local economies, and test it using both the cross-sectional and time-series variation across labor markets.
\end{abstract}

\section{George 3. Borjas}

Department of Economics, 0508

University of California, San Diego

9500 Gilman Drive

La Jolla, CA 92093

and NBER
Valerie A. Ramey

Department of Economics

University of California, San Diego

9500 Gilman Drive

La Jolla, CA 92093

and NBER 
A great deal of recent research in labor economics attempts to document and analyze the huge increase in earnings inequality that occurred in the 1980s. The basic facts, documented in Bluestone and Harrison (1988), Katz and Murphy (1992), Levy and Murnane (1992), and Murphy and Welch (1992) are clear: Earnings inequality and the returns to skills increased substantially beginning in the late-1970s. There was a sizable increase in the wage ratio between highly educated and less educated workers; a rise in the wage ratio between workers with many years of experience and new labor market entrants; an increase in wage inequality among workers within education and experience levels; and an increase in wage inequality among workers in narrowly defined occupation and industry cells.

Although the by-now voluminous literature agrees on these facts, there is much less consensus on the causes of the increase in earnings inequality. Indeed, it seems that a whole new academic industry has developed in which almost every new paper (including this one) attempts yet again to tell a simple story that explains the basic facts.

Several non-mutually exclusive factors have been emphasized as the possible cause of the secular trends in earnings inequality. In an early phase of their work, for instance, Murphy and Welch (1989) argued that the aging of the baby boom, and the resulting decline in the number of new college entrants entering the labor market, may be responsible for the increase in the wage premium accruing to college graduates. Another strand of the literature (Bluestone and Harrison, 1988) argues that the changing industrial mix of the U.S. economy, particularly the shift away from the manufacturing sector and towards service industries, may be partly responsible for the trends. Other researchers (Freeman, 1991) argue that the deunionization of the American economy and/or the decline in the real minimum wage over the 1980s (Blackburn, Bloom, and Freeman, 1990) 
removed the "safety net" supporting the unskilled wage level. Still others argue that the increasing internationalization of the U.S. economy, either through international trade (Murphy and Welch, 1991; Johnson and Stafford, 1992) or through immigration (Borjas, Freeman, and Katz, 1992) may account for the secular trend in earnings inequality. Bishop (1991) even argues that the decline in the quality of American education at the grammar and high school levels, as exhibited by the decline in SAT scores, has lowered the marketability of unskilled workers. Finally, even after accounting for all these factors, a large fraction of the increase remains unexplained and hence some researchers invoke "skill-biased technological change" as the key factor underlying the secular trend in earnings inequality (Bound and Johnson, 1992; Davis and Haltiwanger, 1991; Mincer, 1991; Lawrence and Slaughter, 1993).

In a companion paper (Borjas and Ramey, 1993), we offered our own explanation for the trends in wage inequality. We argued that the trade deficit in durable goods and the average log wage differential between college graduates and less educated workers share the same trend. To illustrate the similarities in patterns of the two series over the last 40 years, Figure 1 graphs the trade deficit in durable goods as a percent of GDP against the average log wage differential of college graduates and high school dropouts, standardized for experience. 1 The graph shows that wage inequality rose during the 1950's, fell during the first half of the 1960's, rose again from 1965 to the early 1970's, fell during part of the 1970's, and then skyrocketed during the 1980's. The graph also shows that the trade deficit in durable goods as a percent of GDP followed much the same pattern, hitting peaks

The wage data are drawn from the 1964-1991 Annual Demographic Files of the Current Population Survey, and from the 1950 and 1960 U.S. Decennial Census, and are standardized for experience. The method of constructing the aggregate data is similar to the method used for the SMSA data analyzed later in this paper; the difference is that only males are included in the aggregate data and that wages are adjusted for experience rather than age. Imports and exports and GDP are in 1987 dollars, and are drawn from CITIBASE. 
and troughs at the same time as the wage series. The only deviation between the two series occurs during the last few years when wage inequality continued to rise, while the trade deficit improved. Murphy and Welch (1992) were the first to note the similarities in patterns, but argued that durable goods trade was only one of several explanations. The graph shows that the trade deficit alone does very well in tracking the movements in wage inequality.

The same statement is not true for the trade deficit in nondurable goods. Figure 2 graphs the trade deficit in nondurable goods as a percent of GDP against the average log wage differential of college graduates and high school dropouts. Although the nondurable good trade deficit also rose during the 1980's, its earlier behavior was very different from that of the wage inequality series. Thus, the two variables do not appear to share the same long-run trend.

In Borjas and Ramey (1993), we used cointegration analysis to confirm the impressions from the graphs. That analysis showed that for the period 1963 to 1988, of the leading explanations for the trends in wage inequality, only the durable goods trade deficit had the same long run trend as the wage inequality series. While many of the other variables, such as de-unionization and $R \& D$ expenditures, also showed substantial increases during the 1980 's, their trends in the early periods were very different from those in the wage inequality series.

In this paper, we present a theoretical interpretation of the time series results, and test the theory using a panel data set on relative wages across SMSA's. Our main idea may be stated simply: imports of durable goods have a strong impact on wage inequality because of the structure of the industries that produce durable goods. Many of these industries are highly concentrated, earn significant rents, and share those rents with less educated workers by paying them higher than average wages. An increase in imports 
lowers the rents of these industries, leading to a decline in the relative wage of less educated workers. To illustrate this idea, we develop a simple two-sector model in which one of the sectors is governed by an oligopoly. We show that the more concentrated is the industry, the greater is the impact of trade on general wage inequality. We use the theory to argue why import competition in an industry such as automobiles is much more deleterious to the wages of the less educated than import competition in an industry such as apparel. We then test our hypothesis using a panel data set on relative wages across SMSA's. We reinterpret our model as a model of local economies, and test it using both the cross-sectional and time-series variation across labor markets.

As has been noted by Karoly and Klerman (1991), there is substantial variation in the secular trends in wage inequality across regions. Some areas of the country experienced a substantial increase, while other areas experienced little, if any, increase. Using regression analysis, we find that the fraction of workers in highly concentrated industries in a local labor market has a significant effect on the overall relative wage in that labor market. Furthermore, we find that foreign competition in the form of immigrant workers has a statistically and economically significant adverse effect on the wages of the less educated. These results hold for a variety of specifications. Thus, we conclude that there is strong evidence linking the secular trends in wage inequality to the increasing internationalization of the U.S. economy.

\section{A Model of Trade, Market Power, Unions and Relative Wages}

\section{A. Overview}

A standard competitive equilibrium model of trade predicts that increased imports will raise the college premium if the traded goods sector uses a higher proportion of less educated workers than the non-traded goods sector. The standard model, however, cannot 
explain why trade in different goods should have differential impacts on the college premium, when the different goods have roughly the same proportions of less educated workers.

Why does an increase in net imports of durable goods have a greater impact on relative wages? There are two related characteristics of these industries that distinguish them. First, the industries that produce durable goods tend to be more concentrated and have higher profits than other industries. For example, the four-firm concentration ratio in 1972 was 99 percent for passenger cars and 90 percent for turbines and turbine generators, while it was 9 percent for women's apparel (Scherer (1980, Table 3.5)). These high concentration ratios tend to manifest themselves in the performance of the industries. For the period 1946 through 1973, the average rate of return in the automobile industry was 16 percent, as opposed to 8.1 percent for all corporations and 9.2 percent for all manufacturing corporations (White (1982)). Second, workers in more concentrated industries tend to earn higher wages. Belman and Weiss (1988) have found the elasticity of the wage with respect to concentration to lie in a range between 0.07 to 0.20 . They found that much of the effect operated through unions, but that there was significant effect that operated independently of unions. Furthermore, Krueger and Summers' (1987, 1988) industry wage premia suggests that durable goods industries have higher wage premia. For example, the premium for total compensation in 1984 is 0.244 in motor vehicles and parts, while it is -0.123 for apparel.

We consider the following story to be a plausible explanation for the link between trade in durable goods and wage inequality: Most of the workers in durable goods manufacturing are high school dropouts or high school graduates. These workers tend to share the rents in their industry in the form of wage premia; workers in industries with larger rents earn a higher premium. When foreign firms enter the market, they capture a 
portion of the industry rents. This entry leads to an increase of the relative wage of college graduates in two ways. First, because the rents of domestic firms have decreased, the wage premium of workers remaining in those industries decreases. Second, to the extent that foreign competition leads to lower employment levels in the concentrated industries, many of the workers must move to the lower paying competitive sectors of the economy. Overall, the wage of less educated workers falls relative to college educated workers.

\section{B. Model}

We formalize this story in the context of a simple model. For a single country, we analyze the general equilibrium of the domestic economy, and take imports as exogenous. Consider an economy with two sectors, 0 and 1 , that produce two consumption goods, $x_{0}$ and $x_{1}$, and that use two types of labor, educated labor $\mathrm{E}$ and less educated labor $\mathrm{L}$. We begin by analyzing sector 1 , which is the noncompetitive sector.

\section{Cournot Oligopoly}

There are a variety of ways to model market power. We choose the Cournot oligopoly model because it gives a simple and intuitive measure of market power. Suppose sector 1 has $n$ firms that behave as Cournot oligopolists participating in a symmetric equilibrium. Foreign firms also produce this good, and they export an exogenous amount $x_{1}^{f}$ to the domestic economy. Total demand for the good $x_{1}$ is given by:

$$
\mathrm{p}_{1}=\alpha_{0}-\alpha_{1} \mathrm{x}_{1}
$$

where $p_{1}$ is the price of the good relative to the price of the other good in the economy, and 
$\alpha_{0}$ and $\alpha_{1}$ are positive parameters. ${ }^{2}$

The demand curve perceived by each domestic firm $\mathrm{i}$ is given by:

$$
\mathrm{p}_{1}=\alpha_{0}-\alpha_{1}\left[\mathrm{x}_{1 \mathrm{i}}+(\mathrm{n}-1) \mathrm{x}_{1}^{\prime}+\mathrm{x}_{1}^{\mathrm{f}}\right]
$$

where $x_{1 i}$ is the amount produced by firm $i, x_{1}^{\prime}$ is the amount produced by each other domestic firm, and $x_{1}^{f}$ is the exogenous amount supplied by foreign firms. The key assumption of the Cournot model is that each firm takes other firms' quantities as given.

We assume that only less educated labor is required to produce $x_{1}$. This assumption captures the notion that the concentrated sector is a more important employer of less educated workers than of educated workers. The production function for firm $i$ is simply

$$
\mathrm{x}_{\mathrm{i} 1}=\mathrm{L}_{\mathrm{i} 1}
$$

where $L_{i 1}$ is the number of less educated workers employed by firm i in sector 1 .

We assume further that each firm bargains with a union over wages and employment. In the Nash bargaining framework, the firm and the union jointly maximize rents, where rents are given by:

$$
\operatorname{Rent}_{\mathrm{i}}=\mathrm{p}_{1} \mathrm{x}_{\mathrm{i} 1}-\mathrm{w}_{0} \mathrm{~L}_{1 \mathrm{i}}
$$

$\mathrm{w}_{0}$, the wage in the competitive sector, is the opportunity cost of labor. The wage $\mathrm{w}_{1}$ will

${ }^{2}$ Later in this section, we will specify the consumer optimization problem from which this demand function is derived. 
be set so that workers receive the competitive wage plus a fraction $\gamma$ of the rents; $\gamma$ depends on the exact specification of the union's objective function. For simplicity, we will assume that $\gamma$ is constant. ${ }^{3}$

Given maximization of rents by each firm and its workers, we have equilibrium production of $x_{i 1}$ :

$$
x_{i 1}=\frac{\alpha_{0}-w_{0}-\alpha_{1} x_{1}^{f}}{\alpha_{1}(n+1)}
$$

and equilibrium rents of firm $i$ and its workers:

$$
\operatorname{Rents}_{i}=\frac{\left(\alpha_{0}-\mathrm{w}_{0}-\alpha_{1} \mathrm{x}_{1}^{\mathrm{f}}\right)^{2}}{\alpha_{1}(\mathrm{n}+1)^{2}}
$$

The workers employed by the firm receive the wage:

(2) $\mathrm{w}_{1}=\mathrm{w}_{0}+\gamma \frac{\alpha_{0}-\mathrm{w}_{0}-\alpha_{1} \mathrm{x}_{1}^{\mathrm{f}}}{\mathrm{n}+1}$.

Under the assumption of a symmetric equilibrium, domestic industry output is simply $\mathrm{nx}_{\mathrm{i} 1}$. Thus, total labor used in industry 1 in the domestic country is given by:

$$
\mathrm{L}_{1}=\frac{\mathrm{n}}{\mathrm{n}+1} \frac{\alpha_{0}-\mathrm{w}_{0}-\alpha_{1} \mathrm{x}_{1}^{\mathrm{f}}}{\alpha_{1}}
$$

3The specification of the interaction between the firm and the union is identical to the one used in Abowd and Lemieux (1992). 
Note that the wage $w_{1}$ is not allocative, in the sense that labor demand does not depend on $w_{1}$. This fact implies that the demand for labor in this sector will generally not equal the supply of labor to this sector. We assume that the parameter values are such that supply always exceeds demand.

We will now discuss the partial equilibrium effects of imports on this sector, taking the rest of the economy as given. First, it is clear from equation (2) that an increase in imports decreases $w_{1}$. An increase in imports leads to a decline in rents, so the wage premium declines. We can also study how this effect differs when the concentration of the industry changes. A natural indicator of market power in our model is $n$, the number of firms in the oligopoly; if $\mathrm{n}$ is unity, the industry is monopolistic; as $\mathrm{n}$ increases, the industry becomes more competitive. Market power affects the wage only through its effect on rents per worker. It is easy to see from equation (2) that $\partial^{2} w_{1} /\left(\partial n \partial x_{1}^{f}\right)>0$. That is, the more competitive the industry (the larger the $n$ ), the lower the rents per worker and hence the smaller is the decline in wages.

It is also useful to discuss the interaction of imports and concentration on the wage bill of sector 1 , which is $w_{1} L_{1}$. We must now be careful when we change $n$, though, because varying $n$ changes the relative size of the industry. As is clear from equation (3), $n$ affects the size through the factor $\frac{n}{n+1}$. For the same value of $\left[\alpha_{0}-w_{0}-\alpha_{1} x_{1}^{f}\right] / \alpha_{1}$, a more concentrated industry will be smaller than a less concentrated industry. If we simply calculated the partial derivative $\partial^{2}\left(w_{1} L_{1}\right) / \partial n \partial x_{1}^{f}$, we would be determining not only the impact of market power on import effects, but also the impact of changing the size of the industry. Thus, in order to isolate the effects of changing the market structure, we must make adjustments so that the industry size does not change when n changes.4 There are a

${ }^{4}$ Changing the size of the industry tends to have effects in the opposite direction of those of changing market power. In particular, an increase in imports into a larger industry results in a greater decrease in employment in that industry. 
variety ways of making this adjustment, such as changing the demand parameter $\alpha_{1}$. The easiest way is to multiply $L_{1}$ in equation (3) by the factor $(n+1) / n$ before taking the derivative of $\partial\left(w_{1} L_{1}\right) / \partial x_{1}^{f}$ with respect to $n$.

When we make the adjustment, we see that:

$\frac{\partial^{2}\left(\mathrm{w}_{1} \mathrm{~L}_{1}\right)}{\partial \mathrm{n} \partial \mathrm{x}_{1}^{\mathrm{f}}}:_{\mathrm{L}_{1} \text { invariant to } \mathrm{n}}=2 \gamma\left(\alpha_{0}-\mathrm{w}_{0}-\alpha_{1} \mathrm{x}_{1}^{\mathrm{f}}\right) /(\mathrm{n}+1)^{2}>0$

Thus, the negative impact of imports on the wage bill is stronger when the industry is more concentrated, holding industry size constant. This partial equilibrium result will form the basis for a similar result in the economy-wide equilibrium model.

\section{Rest of the Economy}

We now briefly sketch the structure of the rest of the economy. Industry 0 is the competitive sector. We assume that the production function for this industry is Cobb-Douglas, with inputs of educated $\mathrm{E}$ and less-educated labor $\mathrm{L}_{0}$. Maximization of profits gives the following first-order conditions:

$$
\mathrm{w}_{0}=\beta \mathrm{L}_{0}^{\beta-1} \mathrm{E}^{1-\beta}
$$

$$
w_{e}=(1-\beta) L_{0}^{\beta} E^{-\beta}
$$

where $w_{0}$ is the wage of less educated workers in this sector, $w_{e}$ is the wage of educated workers, the price of $x_{0}$ has been normalized to one, and $\beta$ lies between 0 and 1 . These conditions simply equate the wage of each type of labor to its marginal product. 
To abstract from distributional effects, we assume there is a representative worker-consumer, who supplies both types of labor. ${ }^{5}$ This consumer has the utility function:

$\mathrm{U}=\mathrm{x}_{0}+\alpha_{0} \mathrm{x}_{1}-\frac{1}{2} \alpha_{1} \mathrm{x}_{1}^{2}, \alpha_{0}, \alpha_{1}>0$

and labor endowments:

(6) $\mathrm{L}_{0}+\mathrm{L}_{1} \leq 1$,

(7) $\mathrm{E} \leq \mathrm{E}$,

Given prices, it is easy to show that the consumer's demand function for $x_{1}$ is exactly as given in equation (1). Because the consumer has no disutility of labor, he will supply his labor inelastically, so equations (6) and (7) will hold with equality. The amount of labor supplied to sector 1 will be determined by the demand for labor in that sector, rather than by the consumer's choice because of the assumed presence of excess supply in equilibrium. Thus, the supply of labor to the competitive sector 0 will be the excess of the labor endowment over the amount of labor demanded by sector 1 .

\section{Equilibrium Effects of Foreign Competition}

Because the system of equations is block recursive, we can determine equilibrium $\mathrm{w}_{0}, \mathrm{w}_{1}, \mathrm{w}_{\mathrm{e}}, \mathrm{L}_{0}, \mathrm{~L}_{1}$, and $\mathrm{E}$ using only equations, equations $(2)-(7)$. The ratio of the

5Adding two types of consumers would only complicate the model, and would not change the basic results concerning the effect of foreign competition on relative wages. 
average wage of less educated labor to educated labor is a function of these variables, and can be written as follows:

$\frac{\text { average wage of less educated labor }}{\text { average wage of educated labor }}=\frac{{ }^{w_{0}} \mathrm{~L}_{0}+{ }^{w_{1}} \mathrm{~L}_{1}}{{ }_{\mathrm{w}}}=\left[1+\frac{\mathrm{w}_{1} \mathrm{~L}_{1}}{\mathrm{w}_{0} \mathrm{~L}_{0}}\right] \frac{\beta \mathrm{E}}{1-\beta}$.

Thus, the less educated to educated wage ratio varies with the wage bill in industry 1 relative to the wage bill in industry 0 . To determine how the wage ratio varies with changes in imports of $x_{1}$, we need only determine how the relative wage bills vary.

We first establish the effect of $x_{1}^{f}$ on equilibrium wages and employment. Comparative static exercises give the following results:

$$
\begin{aligned}
& \frac{\mathrm{d} \mathrm{L}_{0}}{\mathrm{dx}}=[\mathrm{n} /(\mathrm{n}+1)] \alpha_{1} /\left[1+\beta(1-\beta) \mathrm{L}_{0}^{\beta-2} \mathrm{E}^{1-\beta}\right]>0 . \\
& \frac{\mathrm{dL}_{1}}{\mathrm{dx}_{1}^{\mathrm{f}}}=-\frac{\mathrm{dL}_{0}}{\mathrm{dx}_{1}^{\mathrm{f}}}<0 \\
& \frac{d w_{0}}{d x_{1}^{f}}=\beta(\beta-1) L_{0}^{\beta-2} E^{1-\beta} \frac{d L_{0}}{d x_{1}^{f}}<0 . \\
& \frac{d w_{1}}{d x_{1}^{f}}=\left[1-\frac{\gamma}{n+1}\right] \frac{d w_{0}}{d x_{1}^{f}}-\frac{\gamma \alpha_{1}}{n+1}<0 .
\end{aligned}
$$

Thus, an increase in imports of the good produced by the oligopoly leads to a shift in labor from the oligopoly sector to the competitive sector, and decreases the wages of the less educated workers in both sectors. Wages decrease in the oligopoly sector because rents 
have decreased. Wages decrease in the competitive sector because the supply of less educated workers has increased.

Combining the results above, it is easy to show:

$$
\frac{d\left[\left(w_{1} L_{1}\right) /\left(w_{0} L_{0}\right)\right]}{d x_{1}^{f}}<0
$$

Thus, an increase in imports of $x_{1}$ shrinks the wage bill in sector 1 relative to the wage bill in sector 0 , resulting in an overall decrease in the average wage of less-educated workers relative to educated workers.

The key question of interest, and the main point of the model, is how the impact of foreign competition on relative wages varies with the amount of market power in the target industry. The result is summarized in the following proposition:

Proposition: Consider an industry characterized by a Cournot oligopoly that engages in Nash bargaining with its workers. If the industry is more concentrated (but does not change in size), an exogenous increase in imports of the good produced by that industry will have a larger negative impact on the economy-wide average wage of less educated workers relative to educated workers.

The result is easily obtained by showing that:

$$
\left.\frac{d^{2}\left[\left(w_{1} L_{1}\right) /\left(w_{0} L_{0}\right)\right]}{d n d x_{1}^{f}}\right|_{L_{1}, L_{0} \text { invariant to } n}>0
$$


In deriving this result, we apply the same adjustment factor as we did in the partial equilibrium analysis above. The positive sign of the cross derivative implies that the negative impact of foreign competition on wage inequality is less when the industry being penetrated is more competitive.

Thus, the model presented in this section supports the intuition in the story we told above. Imports into concentrated industries capture rents that would otherwise be shared with workers in the form of wage premia. The effect should be greater in industries with higher rents.

The model, while simple and specific, raises some very interesting questions. The model suggests that the types of goods that a country imports and exports are important. If import competition occurs in a sector with market power, the foreign producers may capture many of the rents in that industry. To the extent that domestic rents are shared with less educated domestic workers, a shift of industry rents abroad has a negative impact on the relative wage of less educated workers. The effect is greater the more concentrated the industry.

\section{Evidence from Regional Differences}

We now test our theory by reinterpreting the model as applying to different regions of the country. The key assumption required to apply the model in this way is that labor is sufficiently geographically immobile. If labor were perfectly mobile across cities, relative wages would be equalized across labor markets. If labor is partially immobile, so that relative wage movements differ across regions, we would expect that those areas of the country that lose more worker rents would experience a larger increase in the returns to skill. We analyze this hypothesis by analyzing the determinants of the substantial differences that exist in the wage structure across U.S. cities. 


\section{A. Data}

We use data from the 1977-1991 Annual Demographic Files of the Current Population Surveys. The sample period is selected because the 1977 CPS is the first that identifies a relatively large number of SMSAs, and because the measurement of a person's educational attainment changed substantially beginning with the 1992 CPS. The data thus allow us to track wage differentials across consistently-defined education groups for 44 SMSAs through the 1976-1990 period. We restrict our analysis to the sample of workers (both men and women) aged 18-64 who worked full-time in the civilian sector in the year prior to the survey, who were not self-employed or working without pay, and who resided in one of the 44 SMSAs that can be identified in each of the cross-sections (the SMSAs included in the analysis are listed below). ${ }^{6}$

The wage variable used is the natural logarithm of average weekly earnings in the calendar year prior to the survey. All wages were converted to 1982 dollars using the GNP implicit deflator for personal consumption. We delete workers whose weekly earnings fall below $\$ 67$, and we recoded the wage measure for those workers whose earnings were topcoded by multiplying the topcode value times 1.45 in each of the surveys. These refinements of the wage variable match those used by Katz and Murphy (1992) in their comprehensive study of the wage structure. Our underlying wage data, therefore, is roughly comparable to theirs.

Using the worker's completed educational atainment, we categorize workers into one of four skill groups: (1) workers with less than a high school education (or "high school dropouts"); (2) high school graduates; (3) workers with some college education; and (4) workers with at least a college degree. To obtain age-adjusted wage differentials across

\footnotetext{
${ }^{6} \mathrm{~A}$ worker is classified as working full-time if he works more than 48 weeks during the year, and the usual work week lasts at least 30 hours.
} 
these education groups we estimated the following regression model in each of the March CPS files:

(8) $\quad \log w_{i t}=X_{i t} \beta_{t}+\sum_{k=1}^{4} \sum_{j=1}^{4} \gamma_{j k t} S_{i j t}{ }^{*} C_{i k t}+\epsilon_{i t}$

where $w_{i t}$ is the $\log$ weekly earnings of person $i$ in calendar year $t ; X$ is a vector of standardizing variables; $S_{i j t}(j=1, \ldots, 4)$ is a vector of dummy variables indicating the worker's educational attainment, where the $\mathrm{j}$ index corresponds to the education categories defined above; and $C_{i k t}$ is a vector of dummy variables indicating the SMSA, with $k$ indexing the SMSAs. The vector of standardizing variables $\mathrm{X}$ includes a fourth - order polynomial in the worker's age; a dummy variable indicating the worker's gender; and a dummy variable indicating if the worker is white or nonwhite.

The regression coefficients $\gamma$ from equation (8) are used to calculate two measures of the age-adjusted returns to skills for each SMSA in each calendar year. In particular, we calculate the standardized log wage differential between college graduates and high school graduates ("wh" ); and the standardized log wage differential between college graduates and high school dropouts ("w $\mathrm{dp}^{\prime)}$. These wage differentials are given by:

(9a) $\mathrm{w}_{\mathrm{hs}, \mathrm{kt}}=\gamma_{4 \mathrm{kt}}-\gamma_{2 \mathrm{kt}}$

(9b) $\mathrm{w}_{\mathrm{dp}, \mathrm{kt}}=\gamma_{4 \mathrm{kt}}-\gamma_{1 \mathrm{kt}}$

where $k$ indexes the SMSA and $t$ indexes time.

It is well known that there are substantial differences across Census regions in the level and secular trend of measures of income inequality (see, for example, Karoly and 
Klerman, 1992, and Topel, 1993). Table 1 reports the change in the relative wage for the 44 SMSAs in our analysis between 1976 and 1990, while Figures 3 and 4 illustrate the complete time-series for a number of selected SMSAs.

It is evident that the phenomenon of increasing returns to skills was not experienced equally by all metropolitan areas. The increase in the returns to skills in some metropolitan areas, such as Los Angeles, is roughly consistent with the aggregate trend. For example, college graduates in Los Angeles earned about 21.6 percent more than high school graduates and 31.3 percent more than high school dropouts in 1976. By 1990, college graduates in Los Angeles earned 41 percent more than high school graduates and 84 percent more than high school dropouts. In contrast, other metropolitan areas, such as Pittsburgh, barely experienced a change in the return to schooling over the period. College graduates in Pittsburgh earned 39 percent more than high school graduates in 1976, and only 46.8 percent more in 1990 .

\section{B. Empirical Results}

The main objective of our empirical analysis is to test whether our theory, which was formulated to explain the aggregate times series behavior of wages, can also explain the inter-SMSA differences in the evolution of the wage structure during the $1980 \mathrm{~s}$. It is obviously impossible to allocate directly the U.S. trade deficit to different areas of the country. For example, imports of cars into California might well affect wages in Michigan more than wages in California. The key factor is the change in the rents flowing to workers in a city. Because it is difficult to measure these rents at the city level, as an indirect measure, we use the fraction of the workforce in a particular community that is employed in the industries targeted by foreign competition. Our theory implies that those cities that lost the most employment in highly-concentrated industries should have experienced the 
biggest changes in the wage structure. We discuss the definition of the target industries below.

We test the theory by regressing the measures of returns to skill defined in equations (9a) and (9b) on the industrial composition of the labor market in each city at each point in time, as well as vectors of SMSA fixed effects and period fixed effects, and a set of additional explanatory variables: the fraction of the adult population in the SMSA that is foreign-born; the female labor force participation rate in the SMSA; and the locality's unemployment rate. We discuss below the sensitivity of our results to the inclusion of additional control variables (such as the unionization rate in the SMSA). ${ }^{7}$

The main set of regressions are reported in Tables 2 for the college-high school dropout wage differential and in Table 3 for the college-high school graduate wage differential. We begin the analysis by simply including in the regression a variable describing the fraction of the workforce employed in the manufacturing industry in a particular SMSA at a point in time. The first column of the tables documents a strong negative correlation between the returns to skills (however measured) and the fraction of the workforce employed in manufacturing. This correlation is not only statistically significant, but is also numerically important. A 10 percentage point increase in the fraction of the workforce employed in manufacturing decreases the college premium by about 2 to 4 percentage points.

Columns 2 and 3 of the tables document that the negative correlation between the relative importance of the manufacturing sector in a local labor market and the college

${ }^{7}$ The fraction of the adult population in the SMSA that is foreign-born is calculated from the 1970 Census, the 1980 Census, and the 1989 CPS. We interpolated the intervening years. We calculated the female labor force participation rate and the unemployment rate in the SMSA from the March CPS. Finally, the fraction of the labor force in the SMSA that is unionized is obtained from Curme, Hirsch and Macpherson (1990) and Hirsch and Macpherson (1993). 
premium remains even if we include a vector of dummy variable indicating either the year of the observation or the SMSA of the observation. These fixed effects regressions thus indicate the presence of a negative correlation between the manufacturing employment share and the returns to skills either in the cross-section or over time within an SMSA. However, the inclusion of both SMSA and period fixed effects seems to remove much of the variation in the data, so that the strong negative correlation between the manufacturing employment share and the returns to skills vanishes.

We now allow for a more detailed specification of the composition of the manufacturing industry in the community. We decompose manufacturing employment into four categories: the fraction of workers employed in high concentration import industries; the fraction employed in low-concentration import industries; the fraction employed in other durable industries; and the fraction employed in other manufacturing. Our theory suggests that changes in employment in the first of these categories should have the greatest impact on the wage structure.

Selecting the target industries was complicated by the fact that concentration ratios are usually reported for 4-digit SIC industries, whereas the Census classifications (CIC) tend to be at the 3-digit level, and often do not have the same composition as 3-digit SIC industries. We used the following procedure to select industries. We included any CIC manufacturing industry in the high-concentration category if the majority of workers in the industry were in 4-digit industries with 4-firm concentration ratios greater than 40 percent, based on the 1977 Census of Manufacturers. Based on this method we included the following industries in the high concentration ratio group (the numbers in parenthesis are the pre-1983 CIC codes): primary metals $(139,147,148,149)$, engines and turbines (177), farm equipment (178), construction equipment (179), office equipment (188), computers (189), household appliances (199), motor vehicles and parts (219), aircraft and 
parts (227), railroad equipment (229), photographic equipment (248), and watches and clocks (249). All of these industries except for office machines and computers experienced substantial declines in employment during the period of study. Furthermore, all of these industries except household appliances had substantial wage premia in 1984, according to Krueger and Summers (1988). In contrast, the low-concentration industries consisted of two industries that experienced heavy import competition during the period, but which generally had 4-firm concentration ratios under 40. These industries were apparel $(319,327)$ and leather products $(388,389,397)$.

Figure 5 shows the percent of the labor force employed in highly-concentrated import indistries by education in the 1976-1990 period. The data reveal two striking facts. First, the target industries were more important employers of less educated workers than of more educated workers at the beginning of the period under study. In 1976, for example, 9 percent of high school dropouts were employed in these industries, as compared to only 5 percent of college graduates. Second, the percent of less educated workers employed in these target industries shows steep declines at the same time that their relative wages decrease. In particular, the fraction of high school dropouts employed in these industries declined from over 9 percent to under 4 percent between 1976 and 1990, while the fraction of college graduates employed in these industries remained roughly constant over the period.

The scatter plot of the relative wages (one observation for each year for each SMSA) against the fraction of the labor force that is employed in high-concentration import industries is illustrated in Figures 6 and 7. There is an obvious negative correlation between the relative wage of unskilled workers in a community and the fraction of the city's workforce employed in these target industries (the regression line illustrated in the figures summarizes the simple correlation between the two variables). 
Column 5 of Tables 2 and 3 indicates that the negative correlation between the returns to skills and the relative importance of the manufacturing sector in a community is mostly attributable to the strong negative correlation observed between the returns to skills and the percent of the workforce employed in high-concentration import industries. For instance, a 10 percentage point increase in the fraction of workers that are employed in these industries increases the relative wage of high school dropouts by 7.7 percent, and that of high school graduates by 4.2 percent.

The relative importance of employment in high-concentration import industries as a determinant of the returns to skills is particularly evident in the regressions that include vectors of period fixed effects and/or SMSA fixed effects. In every case, the coefficient on employment in high-concentration industries is more negative than for employment in any of the other industries. Employment in low-concentration industries often enters with a positive sign. Even when the regressions control for both sets of fixed effects, the returns to skills are still negatively correlated with the fraction of the workforce employed in high-concentration industries targeted by foreign imports. In fact, the coefficients on the share of employment in these industries are the only ones in the industry vector that remain statistically significant in both Tables 2 and 3 .

The regressions also include a number of control variables which have independent effects on the wage structure. For instance, the fraction of the adult population that is foreign-born consistently has a significant positive effect on the college premium, and particularly on the relative wage of high school dropouts. The coefficient is not only statistically but numerically important. Unskilled workers in cities with relatively large immigrant populations have lower wages (relative to more highly educated workers) than unskilled workers in other cities. Even after controlling for period and SMSA fixed effects, a 10 percent increase in the fraction foreign-born lowers the wage of high school dropouts 
(relative to that of college graduates) by 5.5 percent.

The strong negative impact of immigration on the (relative) unskilled wage differs drastically from the findings reported by most studies in the literature (see Borjas, 1990, for a survey of these results). Most of the studies analyzing the impact of immigrants on the earnings of natives, however, are based on analyses of cross-section data, where the wage of particular native groups in local labor markets are correlated with the fraction of immigrants in the population. Typically, these cross-section studies find only a slight negative correlation between the presence of immigrants in the local labor market and the native wage (Grossman, 1982; Altonji and Card, 1991; and LaLonde and Topel (1991)). More recent research (Borjas, Freeman, and Katz, 1992) relates the time-series of the wages of unskilled workers in the 1980s and the fraction of immigrants in the economy, and suggests that the sizable immigration of unskilled workers during this period may have been an important contributor to the declining relative wage of unskilled workers over the period. Our analysis, in effect, combines both the cross-section comparisons common in the literature with the time-series analysis and reveals a significant adverse impact of immigration on the unskilled relative wage. ${ }^{8}$

Recent work (Grant and Hamermesh, 1981, Topel, 1992) also suggests that the entry of women into the labor market may have had a negative impact on the wage of unskilled workers. Our regressions indicate that the labor market's female labor force participation rate generally has a positive impact on the college premium as long as period fixed effects are not included in the regression. In effect, removing the aggregate

${ }^{8}$ Some caution is required when using these results to infer the impact of immigrants on the wage of native workers. The CPS does not contain information on the birthplace of workers, so that a part of the impact of immigration on the wage structure is probably due to a change in the composition of the workforce. In particular, the entry of relatively unskilled immigrants would reduce the wages of unskilled workers, even if immigrants had no impact on the earnings of natives. 
time-variation in the data removes much of the perhaps spurious correlation between changes in female labor supply and the returns to skills.

Finally, the regressions include the labor market's unemployment rate so as to control for differential impacts of the business cycle. Tables 2 and 3 indicate a strong positive correlation between the unemployment rate and the returns to skills after controlling for period and SMSA fixed effects. In other words, unskilled workers are worse off during periods of high unemployment.

\section{Robustness of the Results}

There is an important sense in which the regression results summarized in Tables 2 and 3 are not surprising. It is well known that workers in high-concentration import industries earn more than other workers, so that a labor market with a higher percentage of workers in these industries will necessarily have a higher average wage for its less educated workers. As a result, the negative correlation between percent employed in high-concentration import industries and the college premium can be interpreted as tautological.

It is instructive, therefore, to investigate if spillover effects are sufficiently important that the negative correlation persists even after we net out this compositional effect. We do this by investigating if the industrial composition of the workforce has an impact on the relative wage of unskilled workers employed outside high-concentration import industries. Table 4 presents regressions identical to those reported earlier, except that the returns to skills have been estimated on the subsample of workers employed outside the high-concentration import industries. To a large extent, these regressions greatly resemble the ones reported earlier. There is, for example, a negative correlation between the fraction of workers employed in the target industries and the college-dropout 
wage ratio. A 10 percent increase in the fraction of the workforce that is employed in high-concentration import industries increases the relative wage of high school dropouts by 8.1 percent, and that of high school graduates by 3.7 percent, even after controlling for both SMSA and period fixed effects.

Our theoretical model suggests that the importance of imports in high-concentration industries on the wage structure works through the fact that these industries are unionized. It is not surprising, therefore, that if the regressions also control for the fraction of the workforce that is a member of a union, the coefficient of the high-concentration employment variable is weakened.

Table 5 presents the basic set of regressions which include the SMSA's unionization rate. As expected, the unionization variable has a negative impact on the college premium in the locality. A 10 percentage point increase in the unionization rate reduces the relative wage of college graduates by .1 to .2 percent (depending on whether the base is high school dropouts or high school graduates). It is important to note, however, that even though the coefficient of the high-concentration import industries share is weakened, it remains numerically and statistically significant even after controlling for period and SMSA fixed effects. In particular, a 10 percent increase in the share of employment in these important industries increases the relative wage of high school dropouts by 4.3 percent, and that of high school graduates by 3.2 percent.

The empirical analysis presented in this section documents a relationship between changes in employment in the high-concentration industries and changes in the wage structure. Thus, the qualitative results support our theoretical interpretation of the time series link between the durable goods trade deficit and aggregate wage inequality. An interesting question to ask is whether the magnitude of the panel data coefficient estimates can explain the increase in the returns to skills observed in the 1980 s. To some extent, this 
experiment is biased against our hypothesis because we are assuming that there are no spillover effects between cities; that is, the SMSA parameter estimates do not account for the fact that the behavior of wages in one city may have an effect on the behavior of wages in other cities. Thus, the numbers obtained should be viewed as a lower bound.

Table 6 uses the basic regressions reported in columns $5-8$ of Tables 2 and 3 to ascertain the extent to which the secular trends in the returns to skills can be explained in terms of changes in the explanatory variables. As reported in row 1 of the table, the change in the log wage ratio between skilled and unskilled workers in our sample of 44 SMSAs was .195 for high school dropouts and .133 for high school graduates. During the same period, the fraction of workers employed in high-concentration import industries declined from 7.3 percent to 4.2 percent, so that this change in the industrial composition of the labor market alone accounts for a 2.4 percentage point decline in the relative wage of high school dropouts, and for a 1.3 percentage point decline in the relative wage of high school graduates. In other words, this variable alone-which is a very rough proxy for the impact of foreign competition of the wage structure-can explain about ten percent of the decline in the relative wage of unskilled workers. Moreover, the calculations indicate that even if we control for SMSA and period fixed effects, the employment decline in the target industries still account for roughly 10 percent of the relative wage of unskilled workers.

The remaining rows of Table 6 illustrate the impact of changes in the other explanatory variables on the secular trend in the returns to skills. For example, the percentage of the work force that is foreign-born in the labor markets under analysis increased from 8.9 to 14.8 percent between 1976 and 1990. As a result, the inflow of immigrants accounts for about a 3 percentage point decline in the relative wage of high school dropouts, but has only a slight impact on the relative wage of high school graduates (particularly if SMSA and period fixed effects are included in the regressions). 
Finally, the regressions also indicate that the 11.2 percentage point increase in the female labor force participation rate (from 56.3 percent in 1976 to 67.5 percent in 1990) accounts for a substantial fraction of the increase in the returns to skills as long as period effects are not included in the regression. Once period effects are accounted for, the impact of the increase in female labor force participation disappears (and actually leads to a reduction in the returns to skills). As noted earlier, the correlation between female labor force participation and changes in the wage structure is to, a large extent, spurious.

\section{Summary}

This paper presents and tests the hypothesis that foreign competition in highly concentrated industries was an important factor underlying the increase in the returns to skills observed during the 1980s. Our theoretical framework suggests that imports of goods produced in concentrated markets have a much larger impact on the wage structure than imports of goods produced in competitive markets. In particular, foreign competition in concentrated industries transfers rents from less educated workers to foreign producers. The more concentrated the domestic industry, the larger is the loss of rents and hence the greater is the decline in the relative wage of less educated workers.

Because our hypothesis singles out particular sectors of the economy as responsible for an important part of the trends in income inequality, we attempted to determine if those cities that experienced declines in employment in high concentration import industries are the cities that experienced the highest increases in income inequality. The empirical evidence strongly supported our hypothesis. There is a strong negative correlation between the share of employment in these industries in a labor market and the relative wages of less-skilled workers both over time within a city, and in a cross-section of cities. Furthermore, even when we do not allow for spillover effects between cities, the 
average change in the share of employment in the high-concentration industries over time can explain ten percent of the average change in wage inequality. We also find that immigration has a substantial impact on the relative wages of high school dropouts.

It might be hard to believe that such a small set of industries could have such a tremendous impact. A deeper look, however, suggests that the hypothesis is not so far-fetched. First, the trade deficit in motor vehicles and parts alone amounts to one percent of GDP. If one believes that this industry has significant rents, then a large part of the trade deficit represents oligopoly rents shifted to foreign producers. Second, the evidence suggested significant spill-over effects for workers in the labor market not employed directly in the target industries. If these spillover effects are also important in the aggregate, then it is not as hard to reconcile the magnitude of the impact with the small employment share of the industries. 


\section{Bibliography}

Abowd, John and Thomas Lemiux, "The Effects oflnternational Competition on Collective Bargaining Outcomes: A Comparison of the United States and Canada," in John Abowd and Richard Freeman, eds. Immigration, Trade, and the Labor Market. University of Chicago Press, Chicago, 1991.

Altonji, Joseph and David Card. "The Effects of Immigration on the Labor Market Outcomes of Less-skilled Natives," in John Abowd and Richard Freeman, eds. Immigration, Trade, and the Labor Market. University of Chicago Press, Chicago, 1991.

Belman, Dale and Leonard W. Weiss. "Concentration, Unionism, and Labor Earnings: A Sample Selection Approach." Review of Economics and Statistics 70 (August 1988): 391-397.

Bishop, John. "Achievement, Test Scores, and Relative Wages," in Workers and Their Wages, Marvin Kosters, ed. Washington, D.C.: The AEI Press, 1991, pp. 146-190.

Blackburn, McKinley, David Bloom, and Richard B. Freeman. "The Declining Positoin of Less-Skilled American Males," in A Future of Lousy Jobs? Gary Burtless, ed. Washington, D.C.: The Brookings Institution, 1990, pp. 31-67.

Bluestone, Barry and Bennet Harrison. The Great U-Turn: Corporate Restructuring and the Polarization of America. New York: Basic Books, 1988.

Borjas, George J. Friends or Strangers: The Impact of Immigrants on the U.S. Economy. New York: Basic Books, 1990.

Borjas, George J., Richard B. Freeman, and Lawrence F. Katz. "On the Labor Market Effects of Immigration and Trade," in George J. Borjas and Richard B. Freeman, eds., Immigration and the Workforce: Economic Consequences for the United States and Source Areas. Chicago, IL: University of Chicago Press, 1992.

Borjas, George J. and Valerie A. Ramey. "Time Series Evidence on the Source of Trends in Wage Inequality," UCSD manuscript, 1993.

Bound, John and George Johnson. "Wages in the United States During the 1980s and Beyond," in Workers and Their Wages, Marvin Kosters, ed. Washington, D.C.: The AEI Press, 1991, pp. 77-103.

Bound, John and George Johnson. "Changes in the Structure of Wages in the 1980s: An Evaluation of Alternative Explanations," American Economic Review 82 (June 1992): 371-392.

Curme, Michael, Barry Hirsch, and David Macpherson. "Union Membership and Contract Coverage in the United States, 1983-1988." Industrial and Labor Relations Review 44 (October 1990): $5-33$. 
Davis, Steven J. and John Haltiwanger. "Wage Dispersion Between and Within U.S. Manufacturing Plants, 1963-86," Brookings Papers on Economic Activities: Microeconomics (1991): $115-180$.

Freeman, Richard B. "How Much Has De-Unization Contributed to the Rise in Male Earnings Inequality," NBER Working Paper No. 3826, August 1991.

Grant, James H. and Daniel Hamermesh, "Labor Market Substitution Among Youths, White Women and Others," Review of Economics and Statistics 63 (August 1981): $354-360$.

Hirsch, Barry T. and David A. Macpherson. "Union Membership and Coverage Files from the Current Population Surveys: Note," Industrial and Labor Relations Studies 46 (April 1993): 574-578.

Johnson, George E. and Frank P. Stafford. "International Competition and Real Wages," manuscript 1992.

Juhn, Chinhui, Kevin M. Murphy, and Brooks Pierce. "Wage Inequality and the Rise in Returns to Skill," Journal of Political Economy 101 (June 1993): 410-442.

Karoly, Lynn A. and Jacob Alex Klerman. "Regional Differences in Increasing Earnings Inequality." Mimeograph, The RAND Corporation, 1991.

Katz, Lawrence F. and Kevin M. Murphy. "Changes in Relative Wages, 1963-1987: Supply and Demand Factors," Quarterly Journal of Economics 107 (February 1992): $35-78$.

Krueger, Alan and Lawrence Summers. "Reflections on the Inter-Industry Wage Structure." in Kevin Lang and Jonathan Leonard, ed. Unemployment and the Structure of Labor Markets. Basil Blackwell, New York, 1987.

Krueger, Alan and Lawrence Summers. "Efficiency Wages and the Inter-Industry Wage Structure." Econometrica 56 (March 1988): 259-294.

Lalonde, Robert and Robert Topel. "Labor Market Adjustments to Increased Immigration," in in John Abowd and Richard Freeman, eds. Immigration, Trade, and the Labor Market. University of Chicago Press, Chicago, 1991.

Lawrence, Robert Z. and Matthew J. Slaughter. "Trade and US Wages: Great Sucking Sound or Small Hiccup?" Harvard manuscript, 1993.

Levy, Frank and Richard Murnane. "Earnings Levels and Earnings Inequality: A Review of Recent Trends and Proposed Explanations," Journal of Economic Literature, 30 (September 1992): 1333-1381..

Mincer, Jacob. "Human Capital, Technology, and the Wage Structure: What do the Time Series Show?" NBER Working Paper No. 3581, 1991.

Murphy, Kevin M. and Finis Welch. "Wage Premiums for College Graduates: Recent Growth and Possible Explanations," Educational Researcher 18 (May 1989): 17-26. 
Murphy, Kevin M. and Finis Welch. "The Role of International Trade in Wage Differentials," in Workers and Their Wages, Marvin Kosters, ed. Washington, D.C.: The AEI Press, 1991, pp. 39-69.

Murphy, Kevin M. and Finis Welch. "The Structure of Wages," Quarterly Journal of Economics 107 (February 1992): 285-326.

Scherer, F. M. Industrial Market Structure and Economic Performance, 2nd edition. Houghton Mifflin Co, Boston, 1980.

Topel, Robert. "Wage Inequality and Regional Labor Market Performance in the United States," manuscript 1992. 
TABLE 1. RETURNS TO SKILLS IN METROPOLITAN AREAS, 1976, 1990

\begin{tabular}{|c|c|c|c|c|c|c|}
\hline \multirow[b]{2}{*}{ Mctropolitan Arca } & \multirow[b]{2}{*}{ Year } & \multicolumn{2}{|c|}{$\begin{array}{c}\text { Log Wage Ratio of College } \\
\text { Graduates to: }\end{array}$} & \multicolumn{3}{|c|}{ Percent Emplored in: } \\
\hline & & $\begin{array}{l}\text { High School } \\
\text { Dropouts }\end{array}$ & $\begin{array}{c}\text { High School } \\
\text { Graduates }\end{array}$ & Manufacturing & $\begin{array}{c}\text { High- } \\
\text { Concentration } \\
\text { Import Industries }\end{array}$ & $\begin{array}{r}\text { Sample } \\
\text { Size }\end{array}$ \\
\hline Akron. $\mathrm{OH}$ & $\begin{array}{l}1976 \\
1990\end{array}$ & $\begin{array}{l}0.403 \\
0.656\end{array}$ & $\begin{array}{l}0.129 \\
0.289\end{array}$ & $\begin{array}{l}37.5 \\
31.2\end{array}$ & $\begin{array}{l}8.2 \\
5.2\end{array}$ & $\begin{array}{r}98 \\
130\end{array}$ \\
\hline Albany. NY & $\begin{array}{l}1976 \\
1990\end{array}$ & $\begin{array}{l}0.790 \\
0.517\end{array}$ & $\begin{array}{l}0.517 \\
0.485\end{array}$ & $\begin{array}{l}22.3 \\
13.3\end{array}$ & $\begin{array}{l}4.4 \\
1.8\end{array}$ & $\begin{array}{l}115 \\
155\end{array}$ \\
\hline Atlanta, GA & $\begin{array}{l}1976 \\
1990\end{array}$ & $\begin{array}{l}0.800 \\
0.719\end{array}$ & $\begin{array}{l}0.318 \\
0.444\end{array}$ & $\begin{array}{l}20.0 \\
14.6\end{array}$ & $\begin{array}{l}6.8 \\
3.7\end{array}$ & $\begin{array}{l}250 \\
283\end{array}$ \\
\hline Baltimore, MD & $\begin{array}{l}1976 \\
1990\end{array}$ & $\begin{array}{l}0.618 \\
0.684\end{array}$ & $\begin{array}{l}0.458 \\
0.582\end{array}$ & $\begin{array}{l}22.5 \\
17.9\end{array}$ & $\begin{array}{l}4.5 \\
2.7\end{array}$ & $\begin{array}{l}406 \\
255\end{array}$ \\
\hline Birmingham. AL & $\begin{array}{l}1976 \\
1990\end{array}$ & $\begin{array}{l}0.594 \\
0.851\end{array}$ & $\begin{array}{l}0.332 \\
0.726\end{array}$ & $\begin{array}{l}22.2 \\
14.7\end{array}$ & $\begin{array}{l}9.6 \\
3.4\end{array}$ & $\begin{array}{l}138 \\
127\end{array}$ \\
\hline Boston. MA & $\begin{array}{l}1976 \\
1990\end{array}$ & $\begin{array}{l}0.561 \\
0.586\end{array}$ & $\begin{array}{l}0.272 \\
0.414\end{array}$ & $\begin{array}{l}27.5 \\
18.1\end{array}$ & $\begin{array}{l}6.4 \\
4.9\end{array}$ & $\begin{array}{l}376 \\
880\end{array}$ \\
\hline Buffalo. NY & $\begin{array}{l}1976 \\
1990\end{array}$ & $\begin{array}{l}0.557 \\
0.385\end{array}$ & $\begin{array}{l}0.343 \\
0.224\end{array}$ & $\begin{array}{l}46.5 \\
31.7\end{array}$ & $\begin{array}{r}16.3 \\
8.0\end{array}$ & $\begin{array}{l}188 \\
137\end{array}$ \\
\hline Chicago, IL & $\begin{array}{l}1976 \\
1990\end{array}$ & $\begin{array}{l}0.519 \\
0.752\end{array}$ & $\begin{array}{l}0.350 \\
0.450\end{array}$ & $\begin{array}{l}30.7 \\
23.2\end{array}$ & $\begin{array}{l}6.2 \\
2.7\end{array}$ & $\begin{array}{l}1261 \\
1123\end{array}$ \\
\hline Cincinnati, $\mathrm{OH}$ & $\begin{array}{l}1976 \\
1990\end{array}$ & $\begin{array}{l}0.415 \\
0.665\end{array}$ & $\begin{array}{l}0.184 \\
0.421\end{array}$ & $\begin{array}{l}37.7 \\
27.7\end{array}$ & $\begin{array}{r}11.2 \\
+.5\end{array}$ & $\begin{array}{l}232 \\
276\end{array}$ \\
\hline Clevcland, $\mathrm{OH}$ & $\begin{array}{l}1976 \\
1990\end{array}$ & $\begin{array}{l}0.456 \\
0.699\end{array}$ & $\begin{array}{l}0.271 \\
0.415\end{array}$ & $\begin{array}{l}42.9 \\
28.2\end{array}$ & $\begin{array}{r}14.5 \\
6.1\end{array}$ & $\begin{array}{l}364 \\
315\end{array}$ \\
\hline Columbus. $\mathrm{OH}$ & $\begin{array}{l}1976 \\
1990\end{array}$ & $\begin{array}{l}0.352 \\
0.553\end{array}$ & $\begin{array}{l}0.210 \\
0.380\end{array}$ & $\begin{array}{l}16.6 \\
17.8\end{array}$ & $\begin{array}{l}3.0 \\
2.0\end{array}$ & $\begin{array}{l}1+7 \\
281\end{array}$ \\
\hline Dallas. TX & $\begin{array}{l}1976 \\
1990\end{array}$ & $\begin{array}{l}0.620 \\
0.8+1\end{array}$ & $\begin{array}{l}0.406 \\
0.474\end{array}$ & $\begin{array}{l}28.6 \\
22.3\end{array}$ & $\begin{array}{l}5.6 \\
2.4\end{array}$ & $\begin{array}{l}322 \\
+11\end{array}$ \\
\hline Denver. CO & $\begin{array}{l}1976 \\
1990\end{array}$ & $\begin{array}{l}0.458 \\
0.946\end{array}$ & $\begin{array}{l}0.290 \\
0.491\end{array}$ & $\begin{array}{l}19.3 \\
14.9\end{array}$ & $\begin{array}{l}4.0 \\
3.3\end{array}$ & $\begin{array}{l}386 \\
297\end{array}$ \\
\hline Delroit. MI & $\begin{array}{l}1976 \\
1990\end{array}$ & $\begin{array}{l}0.538 \\
0.610\end{array}$ & $\begin{array}{l}0.380 \\
0.451\end{array}$ & $\begin{array}{l}41.0 \\
30.7\end{array}$ & $\begin{array}{l}25.6 \\
17.5\end{array}$ & $\begin{array}{l}632 \\
918\end{array}$ \\
\hline Fon Worth. TX & $\begin{array}{l}1976 \\
1990\end{array}$ & $\begin{array}{l}0.394 \\
0.745\end{array}$ & $\begin{array}{l}0.299 \\
0.407\end{array}$ & $\begin{array}{l}29.3 \\
17.4\end{array}$ & $\begin{array}{r}11.2 \\
8.6\end{array}$ & $\begin{array}{l}17 ! \\
205\end{array}$ \\
\hline Gañ. IN & $\begin{array}{l}1976 \\
1990\end{array}$ & $\begin{array}{l}0.112 \\
0.803\end{array}$ & $\begin{array}{l}0.207 \\
0.583\end{array}$ & $\begin{array}{l}46.4 \\
33.5\end{array}$ & $\begin{array}{l}35.9 \\
17.8\end{array}$ & $\begin{array}{l}94 \\
30\end{array}$ \\
\hline Grecnsboro. NC & $\begin{array}{l}1976 \\
1990\end{array}$ & $\begin{array}{l}0.531 \\
0.569\end{array}$ & $\begin{array}{l}0.296 \\
0.420\end{array}$ & $\begin{array}{l}45.8 \\
36.0\end{array}$ & $\begin{array}{l}0.6 \\
1.2\end{array}$ & $\begin{array}{l}106 \\
310\end{array}$ \\
\hline Houston. TX & $\begin{array}{l}1976 \\
1990\end{array}$ & $\begin{array}{l}0 .+52 \\
0.877\end{array}$ & $\begin{array}{l}0.255 \\
0.513\end{array}$ & $\begin{array}{l}20.5 \\
11.3\end{array}$ & $\begin{array}{l}3.5 \\
1.3\end{array}$ & $\begin{array}{l}+55 \\
+76\end{array}$ \\
\hline Indianapolis. CA & $\begin{array}{l}1976 \\
1990\end{array}$ & $\begin{array}{l}0.532 \\
0.650\end{array}$ & $\begin{array}{l}0.317 \\
0.410\end{array}$ & $\begin{array}{l}29.8 \\
26.7\end{array}$ & $\begin{array}{l}9.7 \\
3.8\end{array}$ & $\begin{array}{r}198 \\
69\end{array}$ \\
\hline Kansas Cily, MO & $\begin{array}{l}1976 \\
1990\end{array}$ & $\begin{array}{l}0.313 \\
0.437\end{array}$ & $\begin{array}{l}0.216 \\
0.3+0\end{array}$ & $\begin{array}{r}24.6 \\
9.9\end{array}$ & $\begin{array}{l}6.9 \\
1.2\end{array}$ & $\begin{array}{l}244 \\
278\end{array}$ \\
\hline Los Angeles. CA & $\begin{array}{l}1976 \\
1990\end{array}$ & $\begin{array}{l}0.578 \\
0.841\end{array}$ & $\begin{array}{l}0.311 \\
0.471\end{array}$ & $\begin{array}{l}29.6 \\
25.8\end{array}$ & $\begin{array}{l}8.1 \\
5+\end{array}$ & $\begin{array}{l}1320 \\
1793\end{array}$ \\
\hline Mlianii. FL & $\begin{array}{l}1976 \\
1990\end{array}$ & $\begin{array}{l}0.735 \\
0.8+6\end{array}$ & $\begin{array}{l}0.535 \\
0.467\end{array}$ & $\begin{array}{l}18.2 \\
12.1\end{array}$ & $\begin{array}{l}1.2 \\
0.9\end{array}$ & $\begin{array}{l}277 \\
413\end{array}$ \\
\hline
\end{tabular}




\begin{tabular}{|c|c|c|c|c|c|c|}
\hline Milwaukee, WI & $\begin{array}{l}1976 \\
1990\end{array}$ & $\begin{array}{l}0.553 \\
0.588\end{array}$ & $\begin{array}{l}0.337 \\
0.563\end{array}$ & $\begin{array}{l}38.0 \\
32.5\end{array}$ & $\begin{array}{r}14.4 \\
5.5\end{array}$ & $\begin{array}{l}254 \\
218\end{array}$ \\
\hline Minn.-St. Paul, MN & $\begin{array}{l}1976 \\
1990\end{array}$ & $\begin{array}{l}0.589 \\
0.590\end{array}$ & $\begin{array}{l}0.446 \\
0.299\end{array}$ & $\begin{array}{l}27.2 \\
20.6\end{array}$ & $\begin{array}{l}4.7 \\
3.0\end{array}$ & $\begin{array}{l}350 \\
320\end{array}$ \\
\hline Nassau-Sufrolk, NY & $\begin{array}{l}1976 \\
1990\end{array}$ & $\begin{array}{l}0 .+71 \\
0.628\end{array}$ & $\begin{array}{l}0.281 \\
0.405\end{array}$ & $\begin{array}{l}19.0 \\
15.2\end{array}$ & $\begin{array}{l}5.1 \\
3.7\end{array}$ & $\begin{array}{l}412 \\
509\end{array}$ \\
\hline New Orleans. LA & $\begin{array}{l}1976 \\
1990\end{array}$ & $\begin{array}{l}0.481 \\
0.815\end{array}$ & $\begin{array}{l}0.292 \\
0.669\end{array}$ & $\begin{array}{r}13.9 \\
5.3\end{array}$ & $\begin{array}{l}1.5 \\
0.0\end{array}$ & $\begin{array}{l}185 \\
115\end{array}$ \\
\hline Ncw York, NY & $\begin{array}{l}1976 \\
1990\end{array}$ & $\begin{array}{l}0.660 \\
0.894\end{array}$ & $\begin{array}{l}0.342 \\
0.505\end{array}$ & $\begin{array}{l}20.4 \\
12.7\end{array}$ & $\begin{array}{l}1.6 \\
0.8\end{array}$ & $\begin{array}{l}1357 \\
1604\end{array}$ \\
\hline Newark, NJ & $\begin{array}{l}1976 \\
1990\end{array}$ & $\begin{array}{l}0.492 \\
1.100\end{array}$ & $\begin{array}{l}0.355 \\
0.520\end{array}$ & $\begin{array}{l}39.1 \\
24.7\end{array}$ & $\begin{array}{l}5.4 \\
2.8\end{array}$ & $\begin{array}{l}296 \\
482\end{array}$ \\
\hline Norfolk, VA & $\begin{array}{l}1976 \\
1990\end{array}$ & $\begin{array}{l}0.7+5 \\
0.5+0\end{array}$ & $\begin{array}{l}0.567 \\
0.514\end{array}$ & $\begin{array}{l}19.3 \\
18.8\end{array}$ & $\begin{array}{l}5.5 \\
0.6\end{array}$ & $\begin{array}{l}104 \\
147\end{array}$ \\
\hline $\begin{array}{l}\text { Patterson-Clifton- } \\
\text { Passaic. NJ }\end{array}$ & $\begin{array}{l}1976 \\
1990\end{array}$ & $\begin{array}{l}0.688 \\
0.8+5\end{array}$ & $\begin{array}{l}0.350 \\
0.521\end{array}$ & $\begin{array}{l}35.1 \\
26.8\end{array}$ & $\begin{array}{l}2.1 \\
3.0\end{array}$ & $\begin{array}{l}256 \\
357\end{array}$ \\
\hline Philadclphia. PA & $\begin{array}{l}1976 \\
1990\end{array}$ & $\begin{array}{l}0.497 \\
0.760\end{array}$ & $\begin{array}{l}0.270 \\
0.482\end{array}$ & $\begin{array}{l}29.6 \\
22.0\end{array}$ & $\begin{array}{l}4.4 \\
2.6\end{array}$ & $\begin{array}{l}695 \\
884\end{array}$ \\
\hline Pillsburgh. PA & $\begin{array}{l}1976 \\
1990\end{array}$ & $\begin{array}{l}0.618 \\
0.638\end{array}$ & $\begin{array}{l}0.387 \\
0.468\end{array}$ & $\begin{array}{l}35.1 \\
17.4\end{array}$ & $\begin{array}{r}15.8 \\
6.6\end{array}$ & $\begin{array}{l}385 \\
332\end{array}$ \\
\hline Portand. OR & $\begin{array}{l}1976 \\
1990\end{array}$ & $\begin{array}{l}0.428 \\
0.400\end{array}$ & $\begin{array}{l}0.187 \\
0.333\end{array}$ & $\begin{array}{l}18.8 \\
27.7\end{array}$ & $\begin{array}{l}3.9 \\
4.6\end{array}$ & $\begin{array}{l}155 \\
192\end{array}$ \\
\hline Rochester. NY & $\begin{array}{l}1976 \\
1990\end{array}$ & $\begin{array}{l}0.275 \\
0.488\end{array}$ & $\begin{array}{l}0.159 \\
0.275\end{array}$ & $\begin{array}{l}45.6 \\
33.8\end{array}$ & $\begin{array}{l}28.2 \\
13.3\end{array}$ & $\begin{array}{l}151 \\
206\end{array}$ \\
\hline Sacramento. $\mathrm{Cd}$ & $\begin{array}{l}1976 \\
1990\end{array}$ & $\begin{array}{l}0.379 \\
0.844\end{array}$ & $\begin{array}{l}0.252 \\
0.531\end{array}$ & $\begin{array}{r}6.7 \\
11.7\end{array}$ & $\begin{array}{l}0.0 \\
2.7\end{array}$ & $\begin{array}{l}137 \\
178\end{array}$ \\
\hline San Bcrnardino. CA & $\begin{array}{l}1976 \\
1990\end{array}$ & $\begin{array}{l}0.451 \\
0.706\end{array}$ & $\begin{array}{l}0.257 \\
0.502\end{array}$ & $\begin{array}{l}20.2 \\
20.5\end{array}$ & $\begin{array}{l}3.2 \\
4.9\end{array}$ & $\begin{array}{l}189 \\
261\end{array}$ \\
\hline San Dicgo. CA & $\begin{array}{l}1976 \\
1990\end{array}$ & $\begin{array}{l}0.571 \\
0.887\end{array}$ & $\begin{array}{l}0.451 \\
0.579\end{array}$ & $\begin{array}{l}20.7 \\
20.5\end{array}$ & $\begin{array}{l}6.1 \\
2.8\end{array}$ & $\begin{array}{l}236 \\
228\end{array}$ \\
\hline $\begin{array}{c}\text { San Francisco- } \\
\text { Oakland. CA }\end{array}$ & $\begin{array}{l}1976 \\
1990\end{array}$ & $\begin{array}{l}0.312 \\
0.802\end{array}$ & $\begin{array}{l}0.210 \\
0.351\end{array}$ & $\begin{array}{l}16.3 \\
13.6\end{array}$ & $\begin{array}{l}3.2 \\
1.8\end{array}$ & $\begin{array}{l}549 \\
463\end{array}$ \\
\hline San Jose, CA & $\begin{array}{l}1976 \\
1990\end{array}$ & $\begin{array}{l}0.558 \\
0.711\end{array}$ & $\begin{array}{l}0.359 \\
0.438\end{array}$ & $\begin{array}{l}36.9 \\
47.4\end{array}$ & $\begin{array}{l}10.4 \\
11.3\end{array}$ & $\begin{array}{l}227 \\
189\end{array}$ \\
\hline Santa Ana. CA & $\begin{array}{l}1976 \\
1990\end{array}$ & $\begin{array}{l}0.550 \\
0.771\end{array}$ & $\begin{array}{l}0.376 \\
0.416\end{array}$ & $\begin{array}{l}29.8 \\
26.5\end{array}$ & $\begin{array}{l}8.3 \\
3.9\end{array}$ & $\begin{array}{l}317 \\
318\end{array}$ \\
\hline Scattle. WA & $\begin{array}{l}1976 \\
1990\end{array}$ & $\begin{array}{l}0.220 \\
0.532\end{array}$ & $\begin{array}{l}0.196 \\
0.293\end{array}$ & $\begin{array}{l}24.8 \\
24.9\end{array}$ & $\begin{array}{l}10.8 \\
10.7\end{array}$ & $\begin{array}{l}237 \\
2+7\end{array}$ \\
\hline St. Louis. MO & $\begin{array}{l}1976 \\
1990\end{array}$ & $\begin{array}{l}0.574 \\
0.790\end{array}$ & $\begin{array}{l}0.351 \\
0.457\end{array}$ & $\begin{array}{l}27.9 \\
20.6\end{array}$ & $\begin{array}{l}7.8 \\
6.3\end{array}$ & $\begin{array}{l}385 \\
1+9\end{array}$ \\
\hline $\begin{array}{l}\text { Tampa- } \\
\text { St. Pctersburg. FL }\end{array}$ & $\begin{array}{l}1976 \\
1990\end{array}$ & $\begin{array}{l}0.506 \\
0.718\end{array}$ & $\begin{array}{l}0.301 \\
0.523\end{array}$ & $\begin{array}{l}17.0 \\
11.8\end{array}$ & $\begin{array}{l}0.7 \\
1.9\end{array}$ & $\begin{array}{l}172 \\
374\end{array}$ \\
\hline Washington. D.C. & $\begin{array}{l}1976 \\
1990\end{array}$ & $\begin{array}{l}0.711 \\
0.704\end{array}$ & $\begin{array}{l}0.336 \\
0.481\end{array}$ & $\begin{array}{l}5.0 \\
7.2\end{array}$ & $\begin{array}{l}1.4 \\
1.5\end{array}$ & $\begin{array}{l}738 \\
904\end{array}$ \\
\hline
\end{tabular}


TABLE 2

\section{DETERMINANTS OF WAGE DIFFERENTIAL BETWEEN COLLEGE GRADUATES} AND HIGH SCHOOL DROPOUTS

\begin{tabular}{|c|c|c|c|c|c|c|c|c|}
\hline \multirow[b]{2}{*}{$\begin{array}{l}\text { Variable } \\
\text { Fraction of Workforce } \\
\text { in Manufacturing }\end{array}$} & \multicolumn{8}{|c|}{ Regression } \\
\hline & $\begin{array}{c}(1) \\
-.4393 \\
(.0604)\end{array}$ & $\begin{array}{c}\frac{(2)}{-.3530} \\
(.0586)\end{array}$ & $\begin{array}{l}\frac{(3)}{-.6960} \\
(.1259)\end{array}$ & $\begin{array}{l}\frac{(4)}{-.1536} \\
(.1382)\end{array}$ & $\frac{(5)}{\cdots-}$ & (6) & $\frac{(7)}{--}$ & $\stackrel{(8)}{--}$ \\
\hline $\begin{array}{l}\text { Fraction in High } \\
\text { Concentration } \\
\text { Import Industries }\end{array}$ & -- & $\cdots$ & -- & - & $\begin{array}{l}-.7686 \\
(.1038)\end{array}$ & $\begin{array}{l}-.7696 \\
(.0983)\end{array}$ & $\begin{array}{l}-1.1531 \\
(.2303)\end{array}$ & $\begin{array}{l}-.5076 \\
(.2350)\end{array}$ \\
\hline $\begin{array}{l}\text { Fraction in Low } \\
\text { Concentration } \\
\text { Import Industrics }\end{array}$ & $\cdots$ & $\cdots$ & $\cdots$ & $\cdots$ & $\begin{array}{l}.8047 \\
(.6+75)\end{array}$ & $\begin{array}{l}1.7510 \\
(.6204)\end{array}$ & $\begin{array}{l}1.2226 \\
(.8078)\end{array}$ & $\begin{array}{l}1.8374 \\
(.7781)\end{array}$ \\
\hline $\begin{array}{l}\text { Fraction in Other } \\
\text { Durables }\end{array}$ & $\cdots$ & -- & -- & $--\cdot$ & $\begin{array}{l}-.2632 \\
(.1227)\end{array}$ & $\begin{array}{l}-.0505 \\
(.1180)\end{array}$ & $\begin{array}{l}-.4961 \\
(.2129)\end{array}$ & $\begin{array}{l}-.0083 \\
(.2123)\end{array}$ \\
\hline $\begin{array}{l}\text { Fraction in Other } \\
\text { Manufacturing }\end{array}$ & $\cdots$ & -- & $\cdots$ & $\cdots$ & $\begin{array}{l}-.1650 \\
(.1586)\end{array}$ & $\begin{array}{l}-.1593 \\
(.1498)\end{array}$ & $\begin{array}{l}-.6960 \\
(.2626)\end{array}$ & $\begin{array}{l}-.2430 \\
(.2577)\end{array}$ \\
\hline $\begin{array}{l}\text { Fraction of Population } \\
\text { Forcign-Born }\end{array}$ & $\begin{array}{l}.5493 \\
(.06+8)\end{array}$ & $\begin{array}{l}.4631 \\
(.0629)\end{array}$ & $\begin{array}{l}1.2825 \\
(.1818)\end{array}$ & $\begin{array}{l}.5450 \\
(.1990)\end{array}$ & $\begin{array}{l}.4532 \\
(.0771)\end{array}$ & $\begin{array}{l}.2888 \\
(.0751)\end{array}$ & $\begin{array}{l}1.3304 \\
(.1826)\end{array}$ & $\begin{array}{l}.5819 \\
(.2010)\end{array}$ \\
\hline $\begin{array}{l}\text { Fraction of Wonien } \\
\text { in Labor Force }\end{array}$ & $\begin{array}{l}.4663 \\
(.0909)\end{array}$ & $\begin{array}{l}.0250 \\
(.1064)\end{array}$ & $\begin{array}{l}.4895 \\
(.1139)\end{array}$ & $\begin{array}{l}-.1918 \\
(.1503)\end{array}$ & $\begin{array}{l}.4375 \\
(.0917)\end{array}$ & $\begin{array}{l}-.0573 \\
(.1055)\end{array}$ & $\begin{array}{l}.4555 \\
(.1150)\end{array}$ & $\begin{array}{l}-.2164 \\
(.1501)\end{array}$ \\
\hline Unemploynent Rate & $\begin{array}{l}.0739 \\
(.1696)\end{array}$ & $\begin{array}{l}-.2224 \\
(.1896)\end{array}$ & $\begin{array}{l}.4980 \\
(.1715)\end{array}$ & $\begin{array}{l}.7163 \\
(.1979)\end{array}$ & $\begin{array}{l}.1970 \\
(.1703)\end{array}$ & $\begin{array}{l}-.0376 \\
(.1872)\end{array}$ & $\begin{array}{l}.4843 \\
(.1714)\end{array}$ & $\begin{array}{l}.6975 \\
(.1978)\end{array}$ \\
\hline $\begin{array}{l}\text { Includes Period } \\
\text { Fived Effects }\end{array}$ & No & Yes & No & Yes & No & Yes & No & Yes \\
\hline $\begin{array}{l}\text { Includes SMSA } \\
\text { Fixed Effects }\end{array}$ & No & No & Yes & Yes & No & No & Yes & Yes \\
\hline R-Squared & .224 & .307 & .476 & .536 & .251 & .350 & .485 & $.5+3$ \\
\hline
\end{tabular}

Notes: Standard errors are reported in parentheses. The regressions have 660 obsen ations. The obsenations are weighted by the inverse of the sampling variance of the dependent variable. 
TABLE 3

DETERMINANTS OF WAGE DIFFERENTIAL BETWEEN COLLEGE GRADUATES AND HIGH SCHOOL GRADUATES

\begin{tabular}{|c|c|c|c|c|c|c|c|c|}
\hline \multirow[b]{2}{*}{$\begin{array}{l}\frac{\text { Variable }}{\text { Fraction of Workforce }} \\
\text { in Manufacturing }\end{array}$} & \multicolumn{8}{|c|}{$\underline{\text { Regression }}$} \\
\hline & $\begin{array}{l}\frac{(1)}{-1801} \\
(.0+21)\end{array}$ & $\begin{array}{c}(2) \\
-.0999 \\
(.0386)\end{array}$ & $\begin{array}{c}(3) \\
-.5073 \\
(.0891)\end{array}$ & $\begin{array}{c}(4) \\
-.0251 \\
(.0942)\end{array}$ & $\stackrel{(5)}{\cdots}$ & $\underline{(6)}$ & $(7)$ & $\stackrel{(8)}{\ldots}$ \\
\hline $\begin{array}{l}\text { Fraction in High } \\
\text { Concentration } \\
\text { Import Industrics }\end{array}$ & $\cdots$ & $\cdots$ & $\cdots$ & -- & $\begin{array}{l}-.4212 \\
(.0723)\end{array}$ & $\begin{array}{l}-.4285 \\
(.06+2)\end{array}$ & $\begin{array}{l}-.9441 \\
(.1631)\end{array}$ & $\begin{array}{l}-.35+2 \\
(.1602)\end{array}$ \\
\hline $\begin{array}{l}\text { Fraction in Low } \\
\text { Concentration } \\
\text { Import Industries }\end{array}$ & -- & $\cdots$ & $\cdots$ & -- & $\begin{array}{c}.1225 \\
(.45+5)\end{array}$ & $\begin{array}{l}1.0721 \\
(.4081)\end{array}$ & $\begin{array}{l}-.1707 \\
(.57+6)\end{array}$ & $\begin{array}{l}.4360 \\
(.5327)\end{array}$ \\
\hline $\begin{array}{l}\text { Fraclion in Other } \\
\text { Durables }\end{array}$ & ... & $\cdots$ & $\cdots$ & - & $\begin{array}{l}-.0214 \\
(.0857)\end{array}$ & $\begin{array}{c}.1836 \\
(.0773)\end{array}$ & $\begin{array}{l}-.1550 \\
(.1507)\end{array}$ & $\begin{array}{c}.2716 \\
(.14+7)\end{array}$ \\
\hline $\begin{array}{l}\text { Fraction in Oller } \\
\text { Manufacturing }\end{array}$ & $\cdots$ & - & $\ldots$ & -- & $\begin{array}{l}.0006 \\
(.1108)\end{array}$ & $\begin{array}{l}-.0088 \\
(.0981)\end{array}$ & $\begin{array}{l}-.5658 \\
(.1857)\end{array}$ & $\begin{array}{l}-.1971 \\
(.1753)\end{array}$ \\
\hline $\begin{array}{l}\text { Fraction of Population } \\
\text { Forcign-Born }\end{array}$ & $\begin{array}{l}.1615 \\
(.0+54)\end{array}$ & $\begin{array}{l}.0753 \\
(.0+16)\end{array}$ & $\begin{array}{l}.5323 \\
(.1298)\end{array}$ & $\begin{array}{l}-.1677 \\
(.1363)\end{array}$ & $\begin{array}{l}.1240 \\
(.0542)\end{array}$ & $\begin{array}{l}-.0386 \\
(.0494)\end{array}$ & $\begin{array}{l}.5683 \\
(.1302)\end{array}$ & $\begin{array}{l}-.1408 \\
(.1376)\end{array}$ \\
\hline $\begin{array}{l}\text { Fraction of Women } \\
\text { in Labor Force }\end{array}$ & $\begin{array}{l}.2487 \\
(.0634)\end{array}$ & $\begin{array}{l}-.1870 \\
(.0698)\end{array}$ & $\begin{array}{l}.4017 \\
(.0808)\end{array}$ & $\begin{array}{l}-.2288 \\
(.1021)\end{array}$ & $\begin{array}{l}.2128 \\
(.0642)\end{array}$ & $\begin{array}{l}-.2625 \\
(.0690)\end{array}$ & $\begin{array}{l}.3564 \\
(.0815)\end{array}$ & $\begin{array}{l}-.2571 \\
(.1019)\end{array}$ \\
\hline Unemployment Rate & $\begin{array}{l}.0149 \\
(.1182)\end{array}$ & $\begin{array}{l}-.27+2 \\
(.12+8)\end{array}$ & $\begin{array}{l}.2552 \\
(.1216)\end{array}$ & $\begin{array}{l}.4189 \\
(.13+9)\end{array}$ & $\begin{array}{l}.0901 \\
(.1190)\end{array}$ & $\begin{array}{l}-.1358 \\
(.1226)\end{array}$ & $\begin{array}{l}.2232 \\
(.1214)\end{array}$ & $\begin{array}{c}.3903 \\
(.1348)\end{array}$ \\
\hline $\begin{array}{l}\text { Includes Period } \\
\text { Fived Efrects }\end{array}$ & No & Yes & No & Yes & No & Yes & No & Yes \\
\hline $\begin{array}{l}\text { Includes SMSA } \\
\text { FiNed Effects }\end{array}$ & No & No & Yes & Yes & No & No & Yes & Yes \\
\hline R-Squared & .083 & .270 & .359 & .475 & .111 & .322 & .371 & .484 \\
\hline
\end{tabular}

Notes: Standard errors are reported in parentheses. The regressions have 660 obsenations. The observations are weighted by the inverse of the sampling variance of the dependent variable. 
TABLE 4

\section{DETERMINANTS OF RETURNS TO SKILLS FOR WORKERS EMPLOYED OUTSIDE IMPORT INDUSTRIES WITH HIGH CONCENTRATION RATIOS}

\begin{tabular}{|c|c|c|c|c|c|c|c|c|}
\hline \multirow[b]{2}{*}{$\begin{array}{l}\text { Variable } \\
\text { Fraction in High } \\
\text { Concentration } \\
\text { Import Industrics }\end{array}$} & \multicolumn{4}{|c|}{$\begin{array}{l}\text { Wage Differential Betiveen College } \\
\text { Graduates and High School Dropouts }\end{array}$} & \multicolumn{4}{|c|}{$\begin{array}{l}\text { Wage Differential Between College } \\
\text { Graduates and High School Graduates }\end{array}$} \\
\hline & $\begin{array}{c}\frac{(1)}{-.3853} \\
(.1207)\end{array}$ & $\begin{array}{c}\frac{(2)}{-.4135} \\
(.1133)\end{array}$ & $\begin{array}{c}\frac{(3)}{-1.5756} \\
(.2734)\end{array}$ & $\begin{array}{c}\frac{(4)}{-.8071} \\
(.2781)\end{array}$ & $\begin{array}{l}\frac{(1)}{.3441} \\
(.07+2)\end{array}$ & $\begin{array}{c}\frac{(2)}{-.3511} \\
(.0661)\end{array}$ & $\begin{array}{c}\frac{(3)}{-.9600} \\
(.1678)\end{array}$ & $\begin{array}{c}\frac{(4)}{-.3693} \\
(.1660)\end{array}$ \\
\hline $\begin{array}{l}\text { Fraction in Low } \\
\text { Concentration } \\
\text { Import Industries }\end{array}$ & $\begin{array}{l}.5740 \\
(.7522)\end{array}$ & $\begin{array}{l}1.7696 \\
(.7130)\end{array}$ & $\begin{array}{l}.5157 \\
(.9560)\end{array}$ & $\begin{array}{l}1.3289 \\
(.9170)\end{array}$ & $\begin{array}{l}.0524 \\
(.4650)\end{array}$ & $\begin{array}{l}.9998 \\
(.4190)\end{array}$ & $\begin{array}{l}-.4592 \\
(.5904)\end{array}$ & $\begin{array}{l}.1272 \\
(.5515)\end{array}$ \\
\hline $\begin{array}{l}\text { Fraction in Other } \\
\text { Durables }\end{array}$ & $\begin{array}{l}-.5317 \\
(.1+22)\end{array}$ & $\begin{array}{l}-.2528 \\
(.1355)\end{array}$ & $\begin{array}{l}-.8921 \\
(.2513)\end{array}$ & $\begin{array}{l}-.3134 \\
(.2499)\end{array}$ & $\begin{array}{l}-.0484 \\
(.0878)\end{array}$ & $\begin{array}{l}.1588 \\
(.0794)\end{array}$ & $\begin{array}{l}-.1482 \\
(.1548)\end{array}$ & $\begin{array}{l}.2784 \\
(.1498)\end{array}$ \\
\hline $\begin{array}{l}\text { Fraction in Other } \\
\text { Manufacturing }\end{array}$ & $\begin{array}{l}-.3+99 \\
(.1839)\end{array}$ & $\begin{array}{l}-.3450 \\
(.1719)\end{array}$ & $\begin{array}{r}-1.7181 \\
(.3080)\end{array}$ & $\begin{array}{r}-1.1819 \\
(.3016)\end{array}$ & $\begin{array}{l}-.0402 \\
(.1133)\end{array}$ & $\begin{array}{l}-.0465 \\
(.1006)\end{array}$ & $\begin{array}{l}-.6768 \\
(.1906)\end{array}$ & $\begin{array}{l}-.3050 \\
(.1814)\end{array}$ \\
\hline $\begin{array}{l}\text { Fraction of Population } \\
\text { Forcign-Born }\end{array}$ & $\begin{array}{l}.4255 \\
(.0893)\end{array}$ & $\begin{array}{l}.2183 \\
(.0860)\end{array}$ & $\begin{array}{l}1.1927 \\
(.2152)\end{array}$ & $\begin{array}{l}.2692 \\
(.2353)\end{array}$ & $\begin{array}{l}.1215 \\
(.0553)\end{array}$ & $\begin{array}{l}. .0426 \\
(.0506)\end{array}$ & $\begin{array}{l}.5442 \\
(.1333)\end{array}$ & $\begin{array}{l}-.1585 \\
(.1419)\end{array}$ \\
\hline $\begin{array}{l}\text { Fraction of Women } \\
\text { in Labor Force }\end{array}$ & $\begin{array}{l}.2910 \\
(.1060)\end{array}$ & $\begin{array}{l}-.3268 \\
(.1205)\end{array}$ & $\begin{array}{l}.1122 \\
(.1350)\end{array}$ & $\begin{array}{l}-.7867 \\
(.1749)\end{array}$ & $\begin{array}{l}.1917 \\
(.0655)\end{array}$ & $\begin{array}{l}-.2957 \\
(.0708)\end{array}$ & $\begin{array}{l}.3230 \\
(.0835)\end{array}$ & $\begin{array}{l}-.2989 \\
(.1055)\end{array}$ \\
\hline Unemploynicut Ratc & $\begin{array}{l}.3339 \\
(.1984)\end{array}$ & $\begin{array}{l}.1029 \\
(.2156)\end{array}$ & $\begin{array}{l}.4500 \\
(.2033)\end{array}$ & $\begin{array}{c}.7332 \\
(.2332)\end{array}$ & $\begin{array}{l}.1011 \\
(.1219)\end{array}$ & $\begin{array}{l}-.1336 \\
(.1259)\end{array}$ & $\begin{array}{c}.1959 \\
(.1248)\end{array}$ & $\begin{array}{l}.3436 \\
(.1395)\end{array}$ \\
\hline $\begin{array}{l}\text { Includes Period } \\
\text { Fixed Effects }\end{array}$ & No & Yes & No & Yes & No & Yes & No & Yes \\
\hline $\begin{array}{l}\text { Includes SMSA } \\
\text { Fixed Effects }\end{array}$ & No & No & Yes & Yes & No & No & Yes & Yes \\
\hline R-Squared & .132 & .270 & .386 & .461 & .081 & .295 & .345 & .454 \\
\hline
\end{tabular}

Notes: Standard crrors are reported in parentheses. The regressions have 660 obseriations. The obscriations are weighted by the inverse of the sampling variance of the dependent variable. 
TABLE 5

DETERMINANTS OF RETURNS TO SKILLS AFTER CONTROLLING FOR UNIONIZATION RATE IN METROPOLITAN AREA.

\begin{tabular}{|c|c|c|c|c|c|c|c|c|}
\hline \multirow[b]{2}{*}{$\begin{array}{l}\text { Variable } \\
\text { Fraction in High } \\
\text { Concentration } \\
\text { Import Industrics }\end{array}$} & \multicolumn{4}{|c|}{$\begin{array}{l}\text { Wage Differential Bctween College } \\
\text { Graduates and High School Dropouts }\end{array}$} & \multicolumn{4}{|c|}{$\begin{array}{l}\text { Wage Differential Between College } \\
\text { Graduates and High School Graduates }\end{array}$} \\
\hline & $\begin{array}{l}\frac{(1)}{-.5302} \\
(.1070)\end{array}$ & $\begin{array}{l}\frac{(2)}{-5712} \\
(.1017)\end{array}$ & $\begin{array}{c}(3) \\
-.8168 \\
(.2+31)\end{array}$ & $\begin{array}{l}\frac{(4)}{-.4259} \\
(.2415)\end{array}$ & $\begin{array}{c}(1) \\
-.2885 \\
(.0753)\end{array}$ & $\begin{array}{c}\frac{(2)}{-.3356} \\
(.0672)\end{array}$ & $\begin{array}{l}\frac{(3)}{-6709} \\
(.1716)\end{array}$ & $\begin{array}{l}\frac{(4)}{-.3162} \\
(.16+8)\end{array}$ \\
\hline $\begin{array}{l}\text { Fraction in Low } \\
\text { Concentration } \\
\text { Import Industrics }\end{array}$ & $\begin{array}{l}.8318 \\
(.6279)\end{array}$ & $\begin{array}{l}1.70+6 \\
(.60+8)\end{array}$ & $\begin{array}{l}1.3+45 \\
(.7989)\end{array}$ & $\begin{array}{l}1.8234 \\
(.7775)\end{array}$ & $\begin{array}{l}.1392 \\
(.4456)\end{array}$ & $\begin{array}{l}1.0496 \\
(.4029)\end{array}$ & $\begin{array}{l}-.0689 \\
(.5661)\end{array}$ & $\begin{array}{l}.+294 \\
(.5328)\end{array}$ \\
\hline $\begin{array}{l}\text { Fraction in Other } \\
\text { Durables }\end{array}$ & $\begin{array}{l}-.2630 \\
(.1189)\end{array}$ & $\begin{array}{l}. .0612 \\
(.1150)\end{array}$ & $\begin{array}{l}-.3737 \\
(.2127)\end{array}$ & $\begin{array}{l}.0008 \\
(.2121)\end{array}$ & $\begin{array}{l}-.0197 \\
(.08+0)\end{array}$ & $\begin{array}{l}.1792 \\
(.0763)\end{array}$ & $\begin{array}{l}-.0526 \\
(.1501)\end{array}$ & $\begin{array}{l}.2761 \\
(.1+49)\end{array}$ \\
\hline $\begin{array}{l}\text { Fraction in Other } \\
\text { Manufacturing }\end{array}$ & $\begin{array}{l}-.0366 \\
(.1550)\end{array}$ & $\begin{array}{l}-.0522 \\
(.1472)\end{array}$ & $\begin{array}{l}-.5405 \\
(.2625)\end{array}$ & $\begin{array}{l}-.2147 \\
(.2582)\end{array}$ & $\begin{array}{l}.0724 \\
(.1095)\end{array}$ & $\begin{array}{l}.0416 \\
(.0976)\end{array}$ & $\begin{array}{l}-.4386 \\
(.18+9)\end{array}$ & $\begin{array}{l}-.1837 \\
(.1759)\end{array}$ \\
\hline $\begin{array}{l}\text { Fraction of Population } \\
\text { Foreign-Born }\end{array}$ & $\begin{array}{l}.5018 \\
(.0751)\end{array}$ & $\begin{array}{l}.3438 \\
(.0738)\end{array}$ & $\begin{array}{l}1.2173 \\
(.1827)\end{array}$ & $\begin{array}{l}.5999 \\
(.2012)\end{array}$ & $\begin{array}{l}.1516 \\
(.0534)\end{array}$ & $\begin{array}{l}-.0121 \\
(.0492)\end{array}$ & $\begin{array}{l}.4786 \\
(.1297)\end{array}$ & $\begin{array}{l}-.1317 \\
(.1379)\end{array}$ \\
\hline $\begin{array}{l}\text { Fraction of Women } \\
\text { in Labor Force }\end{array}$ & $\begin{array}{l}.2101 \\
(.0955)\end{array}$ & $\begin{array}{l}-.2066 \\
(.1059)\end{array}$ & $\begin{array}{l}.3179 \\
(.1189)\end{array}$ & $\begin{array}{l}-.2113 \\
(.1500)\end{array}$ & $\begin{array}{l}.0855 \\
(.0675)\end{array}$ & $\begin{array}{l}-.3318 \\
(.0701)\end{array}$ & $\begin{array}{l}.2485 \\
(.0837)\end{array}$ & $\begin{array}{l}-.2537 \\
(.1020)\end{array}$ \\
\hline Uncmployment Rate & $\begin{array}{l}.4674 \\
(.1703)\end{array}$ & $\begin{array}{l}.3054 \\
(.1917)\end{array}$ & $\begin{array}{l}.50+6 \\
(.1695)\end{array}$ & $\begin{array}{l}.7198 \\
(.1982)\end{array}$ & $\begin{array}{l}.2+31 \\
(.1203)\end{array}$ & $\begin{array}{l}.0275 \\
(.1271)\end{array}$ & $\begin{array}{l}.2+12 \\
(.1196)\end{array}$ & $\begin{array}{l}.4009 \\
(.1353)\end{array}$ \\
\hline $\begin{array}{l}\text { Fraction of Workforce } \\
\text { Unionized }\end{array}$ & $\begin{array}{l}-.0054 \\
(.0008)\end{array}$ & $\begin{array}{r}-.00+7 \\
(.0008)\end{array}$ & $\begin{array}{l}-.0062 \\
(.0016)\end{array}$ & $\begin{array}{l}-.0024 \\
(.0017)\end{array}$ & $\begin{array}{l}-.0031 \\
(.0005)\end{array}$ & $\begin{array}{l}-.0022 \\
(.0005)\end{array}$ & $\begin{array}{l}-.0050 \\
(.0011)\end{array}$ & $\begin{array}{l}-.0011 \\
(.0011)\end{array}$ \\
\hline $\begin{array}{l}\text { Includes Period } \\
\text { Fixed Efrects }\end{array}$ & No & Yes & No & Yes & No & Yes & No & Yes \\
\hline $\begin{array}{l}\text { Includes SMSA } \\
\text { Fixed Errects }\end{array}$ & No & No & Yes & Yes & No & No & Yes & Yes \\
\hline R-Squared & .297 & $.38 j$ & .497 & $.5+5$ & .146. & .340 & .391 & .484 \\
\hline
\end{tabular}

Notes: Standard errors are reported in parenthescs. The regressions have 660 obscriations. The observations are weighted by the inverse of the sampling variance of the dependent variable. 
TABLE 6

\section{PREDICTING SECULAR TREND IN RETURNS TO SKILLS}

\begin{tabular}{|c|c|c|c|c|c|c|c|c|}
\hline & \multicolumn{4}{|c|}{$\begin{array}{l}\text { Wage Differential Betwcen College } \\
\text { Graduates and High School Dropouts }\end{array}$} & \multicolumn{4}{|c|}{$\begin{array}{l}\text { Wage Differential Between College } \\
\text { Graduates and High School Graduates }\end{array}$} \\
\hline $\begin{array}{l}\text { Actual Change in Log Wage Ratio } \\
\text { Observed Between } 1976 \text { and } 1990\end{array}$ & $\frac{(1)}{.195}$ & $\frac{(2)}{195}$ & $\frac{(3)}{.195}$ & $\frac{(4)}{.195}$ & $\frac{(1)}{133}$ & $\frac{(2)}{133}$ & $\frac{(3)}{.133}$ & $\frac{(4)}{133}$ \\
\hline $\begin{array}{l}\text { Change in Log Wage Ratio } \\
\text { Attributable to Change in: }\end{array}$ & & & & & & & & \\
\hline $\begin{array}{l}\text { Fraction of Labor Force Employed } \\
\text { in High-Concentration Import } \\
\text { Industrics }\end{array}$ & .024 & .024 & .035 & .016 & .013 & .013 & .029 & .011 \\
\hline $\begin{array}{l}\text { Fraction of Labor Force That is } \\
\text { Forcign-Born }\end{array}$ & .027 & .017 & .079 & .035 & .007 & -.002 & .038 & -.008 \\
\hline $\begin{array}{l}\text { Fermalc Labor Force Participation } \\
\text { Ratc }\end{array}$ & .049 & -.006 & .051 & -.024 & .024 &. .030 & .040 &. .029 \\
\hline Unemployment Rate & .001 & -.0001 & .002 & .003 & .0003 & .0005 & .0008 & .001 \\
\hline
\end{tabular}


Figure 1. Durable Goods Trade Deficit and the College-High School Dropout Wage Premium

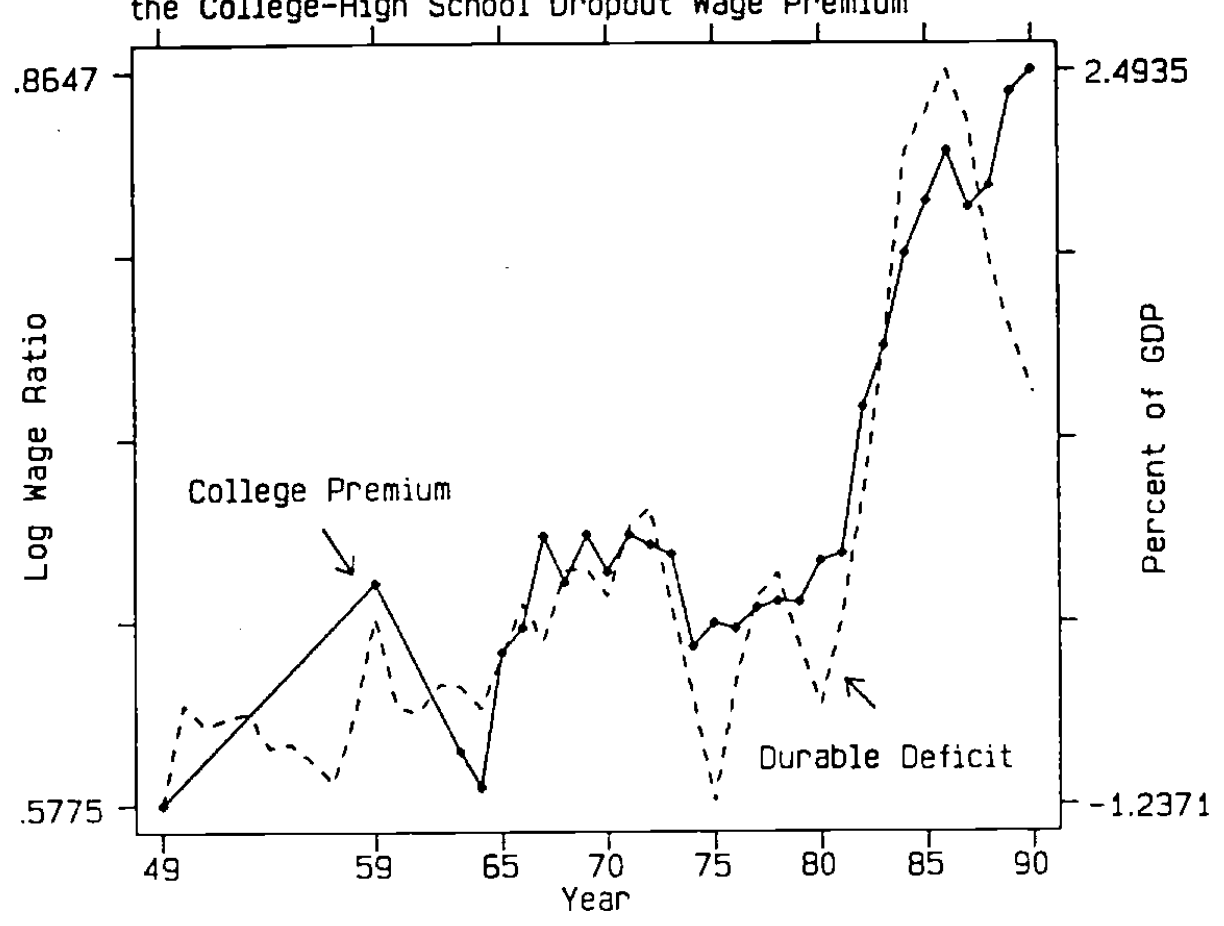


Figure 2. Nondurable Goods Trade Deficit and

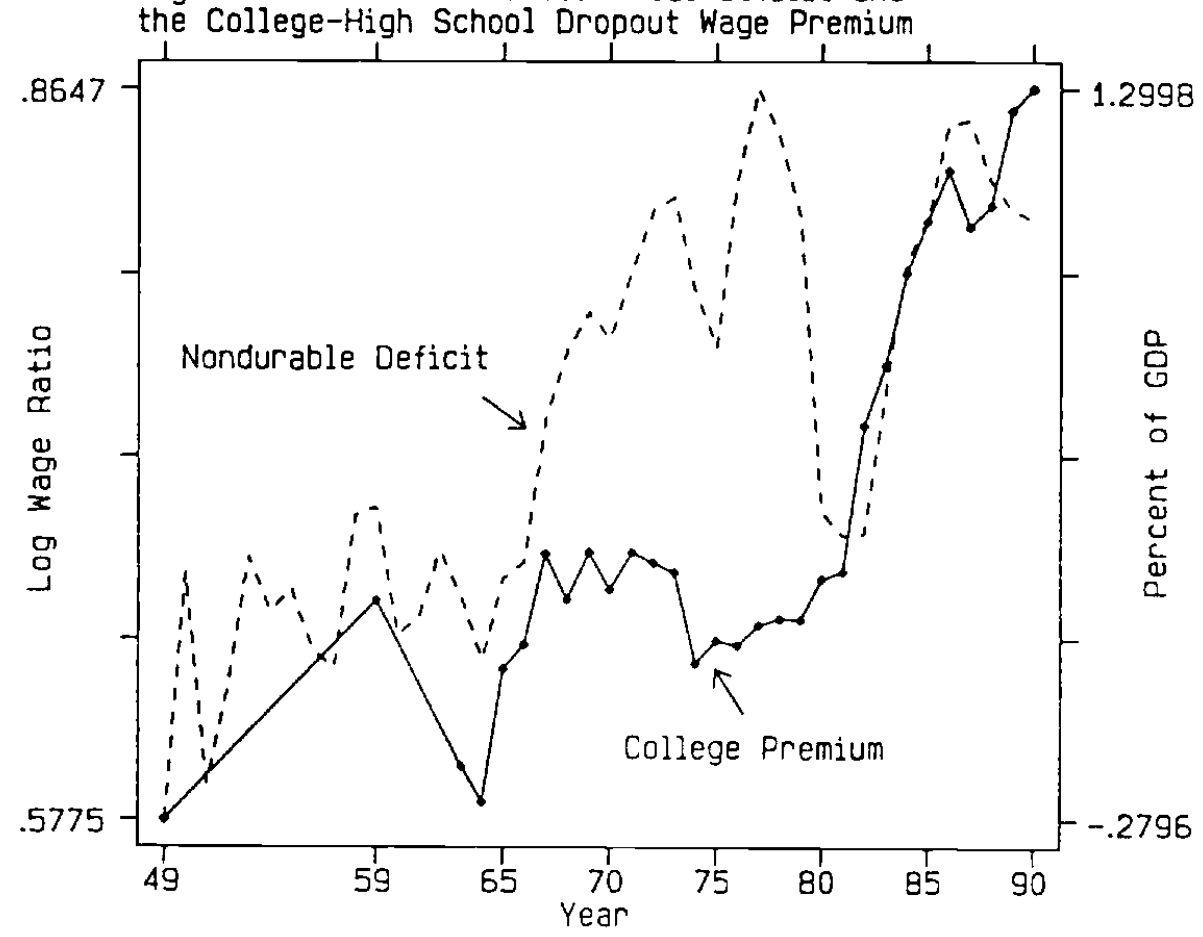




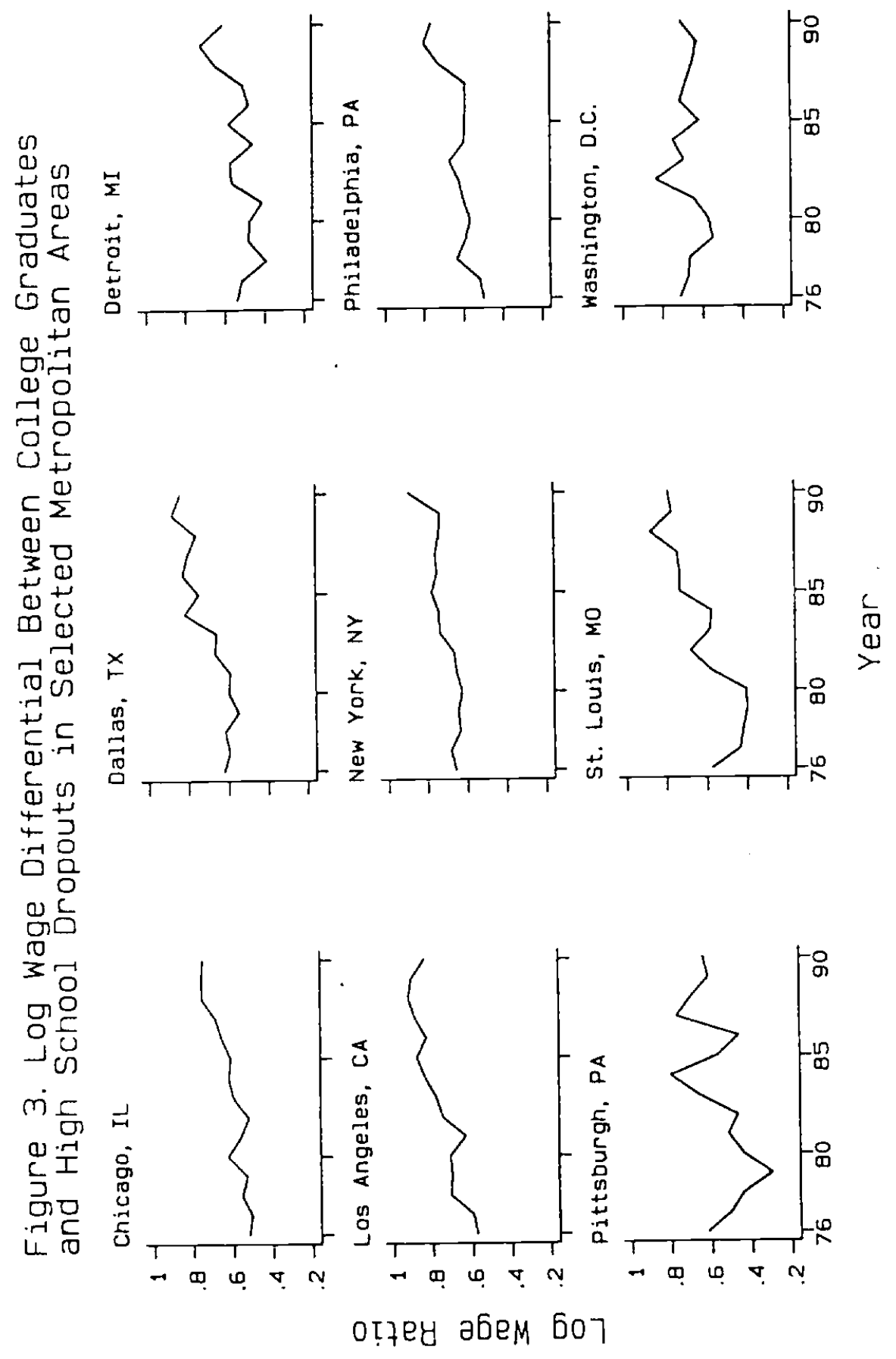




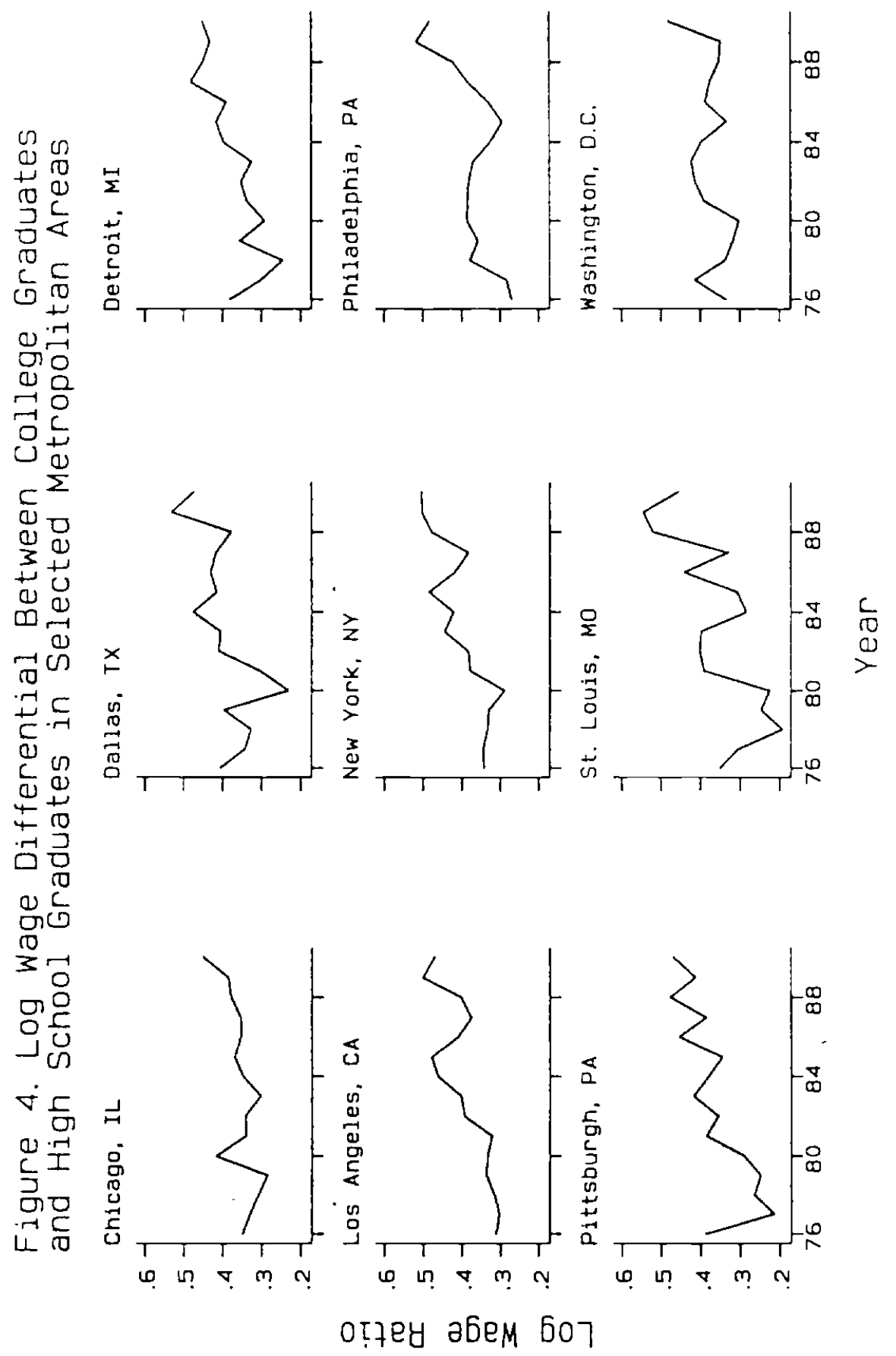


Figure 5. Percent of Labor Force Employed in HighlyConcentrated Import Industries, By Education

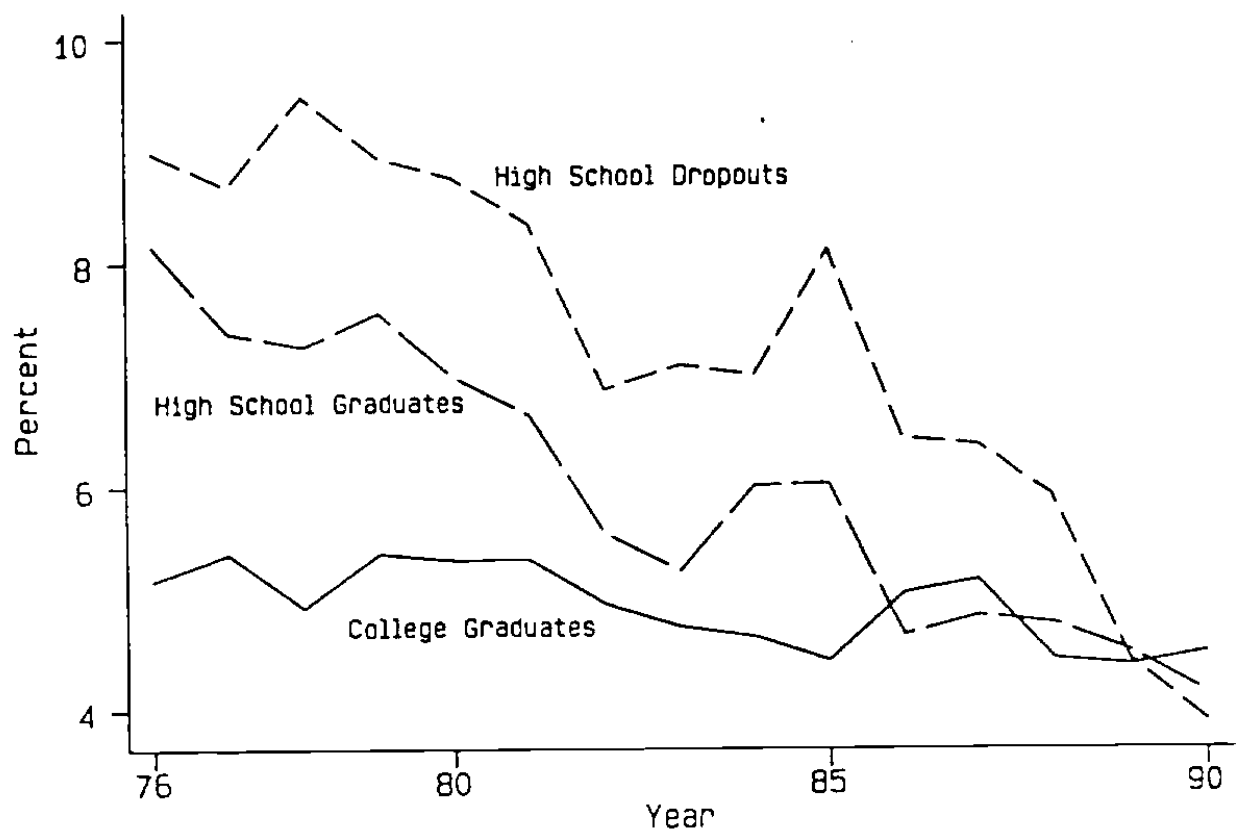


Figure 6. Scatter Between College/H.S. Oropout Wage Ratio and Employment in Target Industries, Across Cities and Over Time

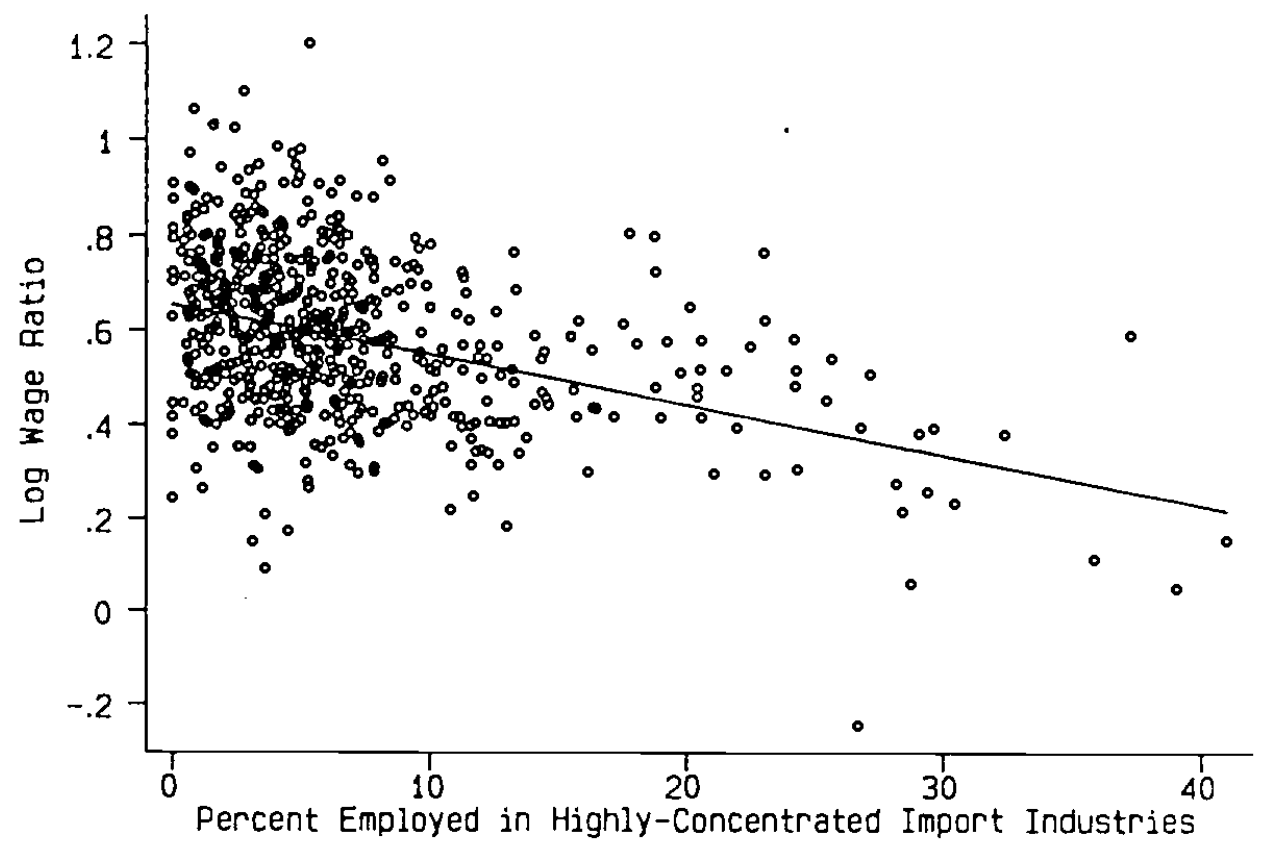


Figure 7. Scatter Between College/H.S. Graduate Wage Ratio and Employment in Target Industries, Across Cities and Over Time

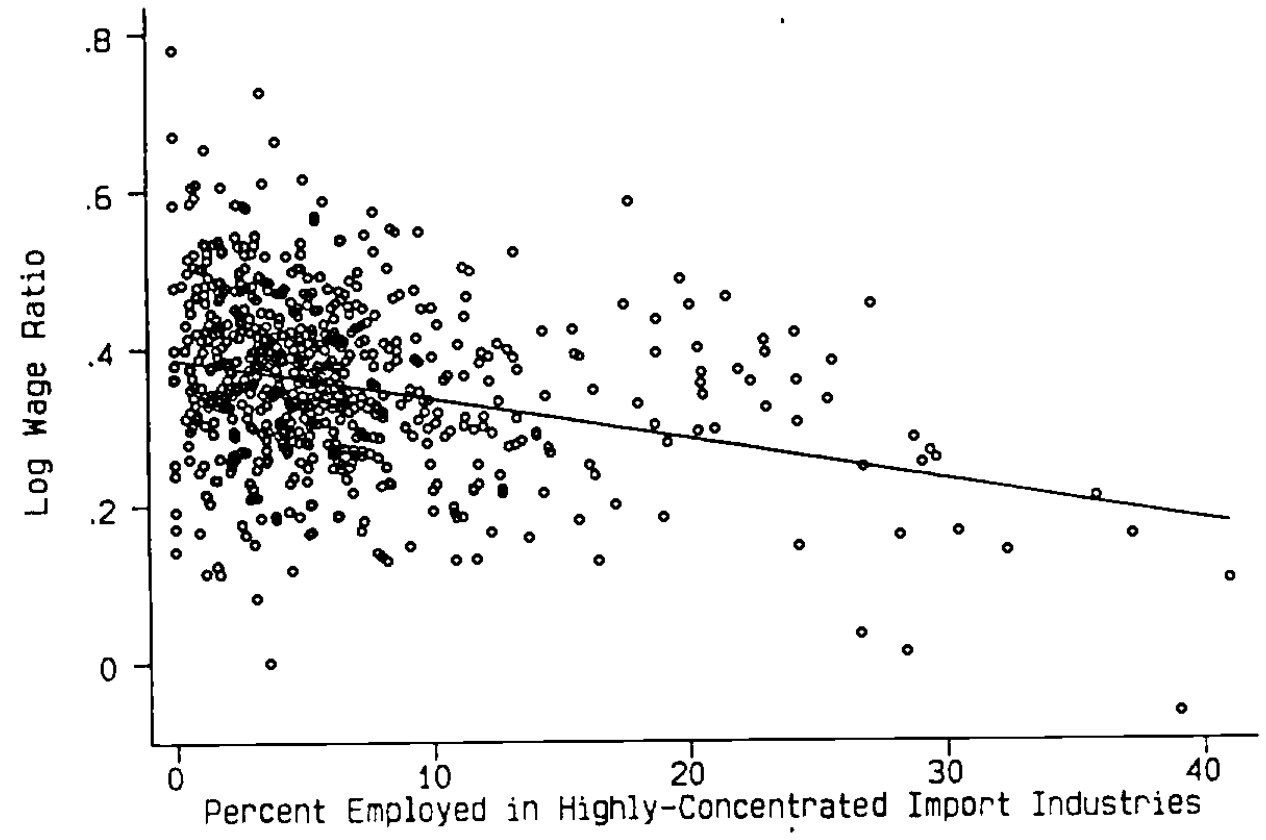

